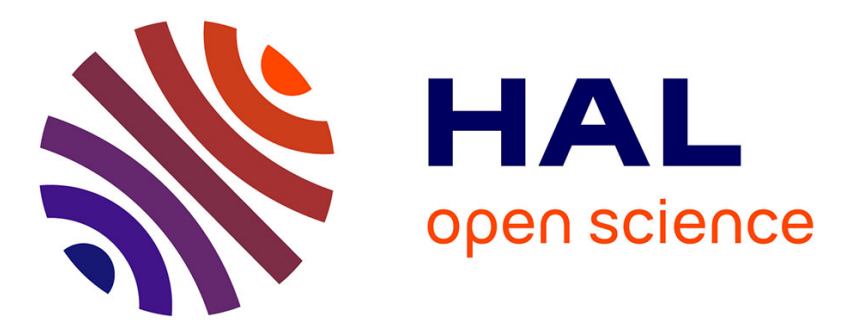

\title{
Impact of canning and storage on apricot carotenoids and polyphenols
}

Carine Le Bourvellec, Barbara Gouble, Sylvie Bureau, Patrice Reling, Romain Bott, Albert Ribas, Jean Marc Audergon, Catherine M.G.C. Renard

\section{To cite this version:}

Carine Le Bourvellec, Barbara Gouble, Sylvie Bureau, Patrice Reling, Romain Bott, et al.. Impact of canning and storage on apricot carotenoids and polyphenols. Food Chemistry, 2018, 240, pp.615-625. 10.1016/j.foodchem.2017.07.147 . hal-01607270

\section{HAL Id: hal-01607270 \\ https://hal.science/hal-01607270}

Submitted on 26 May 2020

HAL is a multi-disciplinary open access archive for the deposit and dissemination of scientific research documents, whether they are published or not. The documents may come from teaching and research institutions in France or abroad, or from public or private research centers.
L'archive ouverte pluridisciplinaire HAL, est destinée au dépôt et à la diffusion de documents scientifiques de niveau recherche, publiés ou non, émanant des établissements d'enseignement et de recherche français ou étrangers, des laboratoires publics ou privés.

\section{(1) (1) $\$$}

Distributed under a Creative Commons Attribution - NonCommercial - NoDerivatives| 4.0 


\section{Accepted Manuscript}

Impact of canning and storage on apricot carotenoids and polyphenols

Carine Le Bourvellec, Barbara Gouble, Sylvie Bureau, Patrice Reling, Romain

Bott, Albert Ribas-Agusti, Jean-Marc Audergon, Catherine M.G.C. Renard

PII:

S0308-8146(17)31301-8

DOI:

http://dx.doi.org/10.1016/j.foodchem.2017.07.147

Reference:

FOCH 21531

To appear in:

Food Chemistry

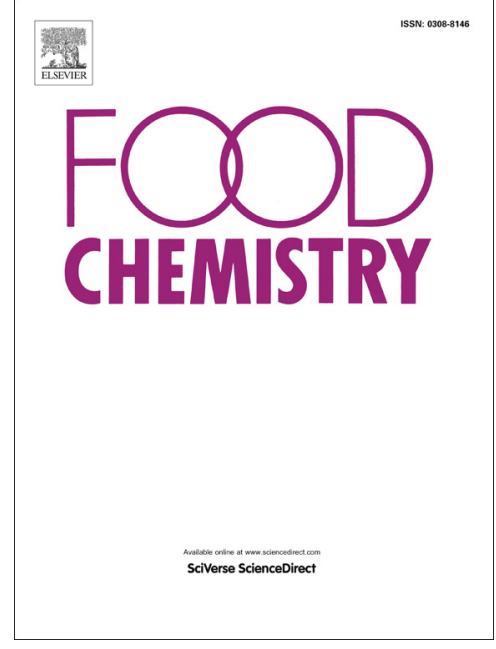

Received Date: $\quad 10$ May 2017

Revised Date: $\quad 25$ July 2017

Accepted Date: $\quad 26$ July 2017

Please cite this article as: Bourvellec, C.L., Gouble, B., Bureau, S., Reling, P., Bott, R., Ribas-Agusti, A., Audergon, J-M., Renard, C.M.G., Impact of canning and storage on apricot carotenoids and polyphenols, Food Chemistry (2017), doi: http://dx.doi.org/10.1016/j.foodchem.2017.07.147

This is a PDF file of an unedited manuscript that has been accepted for publication. As a service to our customers we are providing this early version of the manuscript. The manuscript will undergo copyediting, typesetting, and review of the resulting proof before it is published in its final form. Please note that during the production process errors may be discovered which could affect the content, and all legal disclaimers that apply to the journal pertain. 
Impact of canning and storage on apricot carotenoids and polyphenols

Carine Le Bourvellec ${ }^{\mathrm{a}^{*}}$, Barbara Gouble ${ }^{\mathrm{a}}$, Sylvie Bureau ${ }^{\mathrm{a}}$, Patrice Reling ${ }^{\mathrm{a}}$, Romain Bott $^{\mathrm{a}}$, Albert Ribas-Agusti ${ }^{\mathrm{a}}$, Jean-Marc Audergon ${ }^{\mathrm{b}}$, Catherine M.G.C. Renard ${ }^{\mathrm{a}}$

a : UMR408 SQPOV «Sécurité et Qualité des Produits d'Origine Végétale », INRA, Avignon University, F-84000 Avignon, France

b : UR1052 GAFL «Génétique et Amélioration des Fruits et Légumes », INRA, F84000 Avignon, France

Corresponding authors *

Carine Le Bourvellec (carine.le-bourvellec@inra.fr)

INRA, UMR408 SQPOV «Sécurité et Qualité des Produits d'Origine Végétale »

228 route de l'aérodrome

CS 40509

F-84914 Avignon cedex 9

Tél : +33(0)432722535

Fax : +33(0)432722492 


\section{Abstract}

Apricot polyphenols and carotenoids were monitored after industrial and domestic cooking, and after 2 months of storage for industrial processing.

The main apricot polyphenols were flavan-3-ols, flavan-3-ol monomers and oligomers, with an average degree of polymerization between 4.7 and 10.7 and caffeoylquinic acids. Flavonols and anthocyanins were minor phenolic compounds. Upon processing procyanidins were retained in apricot tissue. Hydroxycinnamic acids, flavan-3-ol monomers, flavonols and anthocyanins leached in the syrup. Flavonol concentrations on per-can basis were significantly increased after processing. Industrial processing effects were higher than domestic cooking probably due to higher temperature and longer duration. After 2 months of storage, among polyphenols only hydroxycinnamic acids, flavan-3-ol monomers and anthocyanins were reduced.

Whichever the processing method, no significant reductions of total carotenoids were observed after processing. The cis- $\beta$-carotene isomer was significantly increased after processing but with a lower extent in domestic cooking. Significant decreased in total carotenoid compounds occurred during storage.

Keywords: polyphenol, carotenoid, sugar, acid, processing 


\section{Highlights}

Apricot carotenoids are more stable than phenolics upon thermal treatments

Polyphenol losses are mainly due to thermal degradation and leaching Apricot phenolic are more stable than carotenoids upon storage 


\section{Introduction}

Apricot (Prunus armeniaca L.) is a fruit of high economic and nutritional relevance. Apricots are a rich source of phenolics and carotenoids that may contribute to reduced risks of several degenerative diseases, such as cancer, cardiovascular diseases, caused by oxidative stress (Terry et al., 2001).

Because of its climacteric characteristic, apricots present a challenge in postharvest storage as they have a very short storage life due to high respiration rate and rapid ripening process linked to ethylene behavior after picking (Gouble et al., 2006). In order to extend their consumption and because of their short seasonal availability, apricots are commonly preserved and consumed after thermal processing methods including canning (halves in syrup for example) and pureeing.

Heat treatments are known to induce significant changes in chemical composition of foods, affecting the bioaccessibility and contents of compounds such as vitamins, carotenoids and polyphenols. Thermal processing of peaches results in a loss of $21 \%$ of total procyanidins (Hong, Barrett, \& Mitchell, 2004) and some of these losses could be attributed to a leaching into the syrup of the low molecular-weight procyanidins. Cooking of pear results also in a preferential retention of the larger procyanidins in the pear sections whereas procyanidins of low degree of polymerisation and caffeoylquinic acid leach into the cooking water (Renard, 2005). The same mechanism has been observed in apple puree (Le Bourvellec, Bouzerzour, Ginies, Regis, Plé, \& Renard, 2011). For cherry products, there is little loss of total phenolics with canning, but approximatively $50 \%$ of total phenolics are redistributed to the syrup (Chaovanalikit \& Wolstrad, 2004a). These results contrast with those of Brownmiller, Howard, \& Prior (2009) who report that after canning berries $65 \%$ of the total procyanidins are retained. The thermal degradative processes depend also on phytomicronutrient structures. Hydroxycinnamic acids and (-)-epicatechin are more labile than flavonol glycosides during 
processing of cherry (Chaovanalikit \& Wolstrad, 2004b). Pasteurization of peach significantly reduces the carotenoid concentrations. Concentration of zeaxanthin and $\beta$-cryptoxanthin are reduced whereas levels of lutein and $\beta$-carotene are unaffected by the heat treatment (Oliveira, Pintado, \& Almeida, 2012). Furthermore, thermal processing also induces a change in isomeric composition of canned tomato, due to the trans to cis isomerization (Lessin, Catigani, \& Schwartz, 1997). Lessin et al. (1997) also found an increase in total $\beta$-carotene, $\alpha$ carotene and $\beta$-cryptoxanthin following canning of carrots, collard greens, spinach and sweet potatoes, but losses in peaches and tomatoes. Overall, the discrepancy observed between the different food matrices might be attributable to the great variability of the shape of the food matrices (Bureau et al., 2015). Canning may improve extractability of carotenoids from cellular matrix, therefore resulting in higher levels in thermally processed products. However, excess heat may also lead to degradation.

Storage may also affect retention of phytomicronutrients. Oliveira et al. (2012) report a reduction of total phenolic in canned peach during the initial 18 days of storage, followed by a plateau. However, the authors did not assay the syrup in this study. Decreases of procyanidin concentration has been reported during storage of canned peaches, however theses losses are due to the migration from fruit matrix to syrup (Hong et al., 2004). Anthocyanin degradation occurs in canned cherries and their syrup stored for 5 months at room temperature (Chaovanalikit \& Wolstrad, 2004a, b), and cyanidin-3-O-rutinoside and pelargonidin-3-O-rutinoside undergo partial hydrolysis during storage (Chaovanalikit \& Wolstrad, 2004b). Oliveira et al. (2012) show that changes in carotenoids occur during storage of peach with increased levels of zeaxanthin and reduction, by decreasing order, of $\beta$ cryptoxanthin $>\beta$-carotene $>$ lutein. Campbell \& Padilla-Zakour (2013) also reported that $\beta$ cryptoxanthin and $\beta$-carotene decrease over the storage period (in canned apricots and peaches) while lutein (in peaches) and zeaxanthin (in both fruits) are lost. Based on HPLC 
data apricot phenolic and carotenoid compounds are more stable under storage than those of peaches (Campbell \& Padilla-Zakour, 2013). However, tomato paste $\beta$-carotene and lycopene remained constant through 12 months of storage (Koh, Charoenprasert, Mitchell, 2011). The contents of carotenoid and phenolic compounds during food processing depend on the chemical structure of the phytomicronutrients, on the fruit matrix, on the intensity of the heat treatment and also on storage.

With the increased recognition of the role of plant-based phenolics and carotenoids in human health and nutrition, it is increasingly important to understand how various processing conditions and storage impact these phytomicronutrients. Nevertheless, information is lacking on how different thermal processing methods and storage of processed products influence the apricot qualities. This study evaluated changes in sugar, acid, polyphenol and carotenoid compositions and contents in response to thermal processing (industrial processing and domestic cooking, halves in syrup) and storage of canned apricots. 


\section{Material and methods}

\section{Chemical}

Acetonitrile of HPLC grade and acetic acid were from Fischer Scientific (Pittsburgh, PA, USA). Tert-Butyl methyl ether (MTBE) of HPLC grade was from Merck (Darmstadt, Germany). Methanol of HPLC grade was from VWR international (Fontenay-sous-bois, France). 5-O-caffeoylquinic acid, (+)-catechin, (-)-epicatechin, sucrose, glucose, fructose, citric acid, $\beta$-carotene, $\beta$-apo8'-carotenal, and toluene- $\alpha$-thiol were from Sigma Aldrich (Darmstadt, Germany). Quercetin, cyanidin-3-O-galactoside, and 3-O-caffeoylquinic acid were obtained from Extrasynthèse (Lyon, France). Malic acid was obtained from R-Biopharm AG (Darmstadt, Germany). Phytoene was obtained from CaroteNature (Lupsingen, Switzerland).

\section{Plant material and sample preparation}

Four apricot cultivars were collected in June 2015 in INRA experimental orchards, Gotheron at St Marcel-les-Valence (Drôme, France) and Amarine at Bellegarde (Gard, France) and in SERFEL (Station d'Expérimentation Régionale pour les Fruits et Légumes) orchard at Saint Gilles (Gard, France): 'Orangered ${ }^{\circledR}$ Bhart', 'Iranien', 'Goldrich' and 'Hargrand'. These various orchards, located in different regions, allowed to have all 4 cultivars at the same two dates (23 and 25/06), imposed by canning schedule. These cultivars presented different colors: 'Orangered ${ }^{\circledR}$ Bhart', a dark orange apricot with red blush, 'Iranien' a green-white cultivar with a little red blush on sunny fruits, 'Goldrich' a dark orange one without blush and 'Hargrand' a pale orange apricot without blush. They were chosen according to their texture evolutions after processing (Ribas-Agusti, Gouble, Bureau, Maingonnat, Audergon, \& Renard, 2017). For each cultivar, about 250 fruits were harvested at a commercial maturity stage. Firmness of entire fruits was assessed by compression test 
(see section physical characterization) in order to obtain samples of homogeneous representative texture hence maturity level for each cultivar and between cultivars. So, for each cultivar, 86 fruits were sorted and divided in three batches: the first batch of 24 fruits was used for analysis of fresh apricots, the second batch of 20 fruits was used for domestic cooking, and the third batch of 42 fruits was used for canning. For each process, part of the fruits was for biochemical analysis and the other part for texture analysis.

\section{Fresh fruit}

For biochemical analysis, three replicates of four fruits each were constituted randomly. In each replicate, fruits were cut into small pieces and immediately frozen using liquid nitrogen. Apricots were then divided in two bags, A and B. Bags A were freeze-dried, stored at $-20{ }^{\circ} \mathrm{C}$, and used for phenolic characterization. Bags B were stored at $-80{ }^{\circ} \mathrm{C}$ and used for infrared, total soluble solids (TSS), titratable acidity (TA), carotenoids, sugars and organic acids.

\section{Canning treatment}

Canning was carried out by the Centre Technique de la Conservation des Produits Agricoles (CTCPA, Avignon, France). The fruits were cleaned, manually cut through the middle and pitted. Six apricot halves were put into each can $(425 \mathrm{~mL})$, to which hot syrup $\left(70^{\circ} \mathrm{C}\right)$ was added $\left(16^{\circ}\right.$ Brix, sucrose $)$. The fruit proportion in the final product varied from $42 \%$ ('Iranien') to $67 \%$ ('Hargrand'). Cans were sealed and then heated at $95{ }^{\circ} \mathrm{C}$. The temperature of the syrup in the can was monitored by placing thermocouples into two cans; it reached $95{ }^{\circ} \mathrm{C}$ after $14 \mathrm{~min}$. and remained at this temperature for 2 min thereafter. Finally cans were sprayed with cold water to reach $30^{\circ} \mathrm{C}$.

For each cultivar, 14 cans of 6 halves each were obtained and distributed as follows:

- 3 cans for biochemical analysis one day after canning; 
- 4 cans for texture analysis one day after canning

- 3 cans for biochemical analysis after 60 days storage at room temperature $\left(22^{\circ} \mathrm{C}\right)$;

- 4 cans for texture analysis after 60 days storage at room temperature $\left(22^{\circ} \mathrm{C}\right)$.

For biochemical analysis, syrup and fruits, of each can, were separated and weighted. Fruits were analyzed as described for fresh ones. Syrup was homogenized and $50 \mathrm{~mL}$ were frozen and stored at $-20{ }^{\circ} \mathrm{C}$ until freeze-drying and polyphenol analysis.

\section{Domestic cooking}

The 20 fruits were cut through the middle and pitted. Apricot halves (40) were plunged in cane sugar syrup $\left(16^{\circ}\right.$ Brix, $\left.900 \mathrm{~mL}\right)$ at $70{ }^{\circ} \mathrm{C}$ and cooked for about $20 \mathrm{~min}$, until a final temperature of $85{ }^{\circ} \mathrm{C}$ was reached inside the apricot halves as monitored with a Fluke 51 K/J thermometer (John Fluke, Everett, Washington, USA). Then apricot halves were immediately drained and cooled on ice bed. The fruit proportion in the containers varied from $22 \%$ ('Iranien') to $29 \%$ ('Hargrand').

After cooking, syrup and fruits were separated, 18 halves, distributed in three samples of six halves, were used for biochemical characterization. Syrup and fruits were weighted. Syrup was homogenized and $50 \mathrm{~mL}$ were frozen and stored at $-20{ }^{\circ} \mathrm{C}$ until freeze-drying and polyphenol analysis.

\section{Physical characterization}

In order to compare the fruits and the cultivars on the same bases, a standardization and an harmonization of fruit batches was performed by using fruits at the same global firmness. Firmness of each fruit was measured by uniaxial compression test with a $50 \mathrm{~mm}$ flat probe using a texture analyzer (Pénélaup, Sérisud, Montpellier, France). The fruit compression strain was kept low (3\% of apricot height) to ensure that no irreversible damage or stress to the fruit occurred. Test operating conditions were conducted with test-speed $10 \mathrm{~cm}$ 
$\min ^{-1}$. Force corresponding to $3 \%$ strain was measured and used to compute the related compression pressure, expressed in Pascal (Grotte et al., 2001). For each cultivar, fruits were sorted by decreasing firmness and 86 fruits were selected with the more homogeneous firmness and dispatched homogeneously into the 3 conditions. The global firmness for 'Orangered ${ }^{\circledR}$ Bhart', 'Goldrich' and 'Hargrand' was $115 \mathrm{kPa}$ (standard deviation 11) (respectively 114, 117 and $115 \mathrm{kPa}$ ). For 'Iranien', due to the imperative date for canning, fruits were less mature, with firmness of $293 \mathrm{kPa}$ (standard deviation 27).

The fruit texture, before and after thermal treatments, was determined by penetrometry test. For each half (10 to 12 by condition), a slice of about $1.5 \mathrm{~cm}$ thick was cut longitudinally and four measurements were made on each slice (Ribas-Agusti et al., 2017). Texture measurements were performed using a multi-purpose texturometer TaPlus (Lloyd, Ametek, Elancourt, France). The system measured the maximum force $(\mathrm{N})$ required to penetrate $9 \mathrm{~mm}$ of pulp, at constant penetration rate $\left(100 \mathrm{~mm} \mathrm{~min}^{-1}\right)$, using a flat cylinder tip $(2.0 \mathrm{~mm}$ diameter).

\section{Mid-infrared spectroscopy}

As described in Bureau et al. (2013), mid-infrared spectra were collected at $23{ }^{\circ} \mathrm{C}$ with a Bruker Tensor 27 FTIR spectrometer (Wissembourg, France) equipped with a horizontal attenuated total reflectance (ATR) sampling accessory and deuterated triglycine sulphate (DTGS) detector. The homogenized (only halves were ground) samples were placed at the surface of the zinc selenide crystal providing six internal reflections into the samples. The sample consistency, a thick liquid, allowed a good contact between sample and crystal and did not require pressing. The spectrum of each sample was obtained by taking the average of 32 scans at a resolution of $4 \mathrm{~cm}^{-1}$, with scanner velocity of $10 \mathrm{KHz}$. The crystal was cleaned between measurements with deionized water and dried with lint-free tissue. 


\section{Analysis methods}

Total Soluble Solids (TSS) were determined with a digital refractometer (PR-101 ATAGO, Norfolk, VA, USA) and expressed in ${ }^{\circ}$ Brix at $20{ }^{\circ} \mathrm{C}$. Titratable acidity (TA) was

determined by titration up to $\mathrm{pH} 8.1$ with $0.1 \mathrm{~mol} \mathrm{~L}{ }^{-1} \mathrm{NaOH}$ and expressed in $\mathrm{mmol} \mathrm{H}^{+} \mathrm{kg}^{-1}$ fresh weight (FW) using an autotitrator (Methrom, Herisau, Switzerland).

Sugars (glucose, fructose, and sucrose) and organic acids (malic acid and citric acid) were quantified using colorimetric-enzymatic methods (R-Biopharm AG, Darmstadt, Germany) and expressed in $\mathrm{g} \mathrm{kg}^{-1} \mathrm{FW}$. These measurements were performed with a SAFAS flx-Xenius XM spectrofluorimeter (SAFAS, Monaco).

TSS, TA, sugars and organic acids were quantified in halve fruit only.

Phenolics were measured by high-performance liquid chromatography (HPLC)-diode array detection (DAD) after thioacidolysis using a method adapted from Le Bourvellec et al. (2011) and Guyot, Marnet, \& Drilleau, (2001) on fruit and syrup. Procyanidins were characterized by thioacidolysis to determine subunit composition, average molecular mass and the average degree of polymerization $(\mathrm{mDP})$. The $\mathrm{mDP}$ of procyanidins was calculated as the molar ratio of all the flavan-3-ol units (thioether adducts plus terminal units) to (-)epicatechin and (+)-catechin corresponding to terminal units. Thioacidolysis was performed on the freeze-dried samples according to the procedure established by Le Bourvellec et al. (2011) and Guyot, Marnet, \& Drilleau, (2001) except that the amount of added concentrated $\mathrm{HCl}$ was increased to take into accound the buffering capacity of the fruit. Precisely weighted powder (c.a. $100 \mathrm{mg}$ for fruit and c.a $1200 \mathrm{mg}$ for syrup) was suspended in $1.5 \mathrm{~mL}$ Eppendorf vial with $400 \mu \mathrm{L}$ of dried methanol acidified by concentrated $\mathrm{HCl}(250 \mathrm{~mL} / \mathrm{L})$ and $800 \mu \mathrm{L}$ of toluene $\alpha$ thiol solution $(50 \mathrm{~mL} / \mathrm{L})$ in dried methanol. The reaction was carried out at $40^{\circ} \mathrm{C}$ for $30 \mathrm{~min}$ with agitation every $10 \mathrm{~min}$. Then, the vials were cooled in an ice bath for at least 5 min. After filtration (PTFE, $0.45 \mu \mathrm{m}$ ), the reaction medium was directly injected (20 $\mu \mathrm{L})$ into 
the HPLC-DAD system. In order to distinguish between native flavan-3-ol monomers and flavan-3-ol monomers coming from the terminal units of procyanidins a 'crude' seed analysis without thiolysis was performed. Precisely weighted powders (c.a. $100 \mathrm{mg}$ for fruit and c.a $1200 \mathrm{mg}$ for syrup) were suspended in $1.5 \mathrm{~mL}$ Eppendorf vial with $1200 \mu \mathrm{L}$ of methanol acidified by acetic acid $(10 \mathrm{~mL} / \mathrm{L})$. The reaction was carried out in an ultrasonic bath during 15 min. After filtration (PTFE, $0.45 \mu \mathrm{m})$, the reaction mixture was directly injected $(20 \mu \mathrm{L})$ into the HPLC-DAD system. Analyses were performed using an Ultra Fast Liquid Chromatography Shimadzu Prominence system (Kyoto, Japan) including two pumps LC20AD Prominence liquid chromatograph UFLC, a DGU-20A5 Prominence degasser, a SIL20ACHT Prominence autosampler, a CTO-20AC Prominence column oven, a SPD-M20A Prominence diode array detector, a CBM-20A Prominence communication bus module and controlled by a LC Solution software (Shimadzu, Kyoto, Japan). Separations were achieved in Le Bourvellec et al. (2011) conditions. Individual compounds were quantified in $\mathrm{mg} \mathrm{kg}^{-1} \mathrm{FW}$ by comparisons with external standards:

-at $280 \mathrm{~nm}$ for (+)-catechin, (-)-epicatechin, (-)-epicatechin benzyl thioether (quantified as (-)-epicatechin);

-at $320 \mathrm{~nm}$ for 3-O-caffeoylquinic acid 5-O-caffeoylquinic acid, and their methylated derivatives obtained during thioacidolysis reaction quantified as their respective nonmethylated equivalents;

-at $350 \mathrm{~nm}$ for quercetin-3-O-glycosides (quantified as quercetin);

-at $540 \mathrm{~nm}$ for cyanidin glycosides (quantified as cyanidin-3-O-glucoside).

Fruit carotenoid extraction was carried out using the micromethod described by Page, Van Stratum, Degrou, \& Renard, (2012), including the addition of $\beta$-apo8'-carotenal used as internal standard. HPLC-DAD analyses were performed using an Ultra Fast Liquid chromatography Shimadzu Prominence system (Kyoto, Japan) as described above. 
Separations were achieved on a $250 \mathrm{~mm} \times 4.6 \mathrm{~mm}$ i.d. $3 \mu \mathrm{m}$ Develosil C30 (Nomura Chemical Co. Ltd., Seto, Aïchi, Japan) protected with a precolumn containing the same stationary phase, in an oven maintained at $30^{\circ} \mathrm{C}$. Elution was performed at a solvent flow rate $1.4 \mathrm{~mL} \min ^{-1}$. The mobile phase was methanol and the polarity gradient was achieved with MTBE, starting with $100 \%$ methanol, increasing to $40 \%$ MTBE in $10 \mathrm{~min}$, then increase up to $60 \% \mathrm{MTBE}$ in $2 \mathrm{~min}$, maintaining that percentage of MTBE for $7 \mathrm{~min}$, return to $100 \%$ Methanol in 2 min and hold for 10 min. Carotenoids were detected at wavelength from 280 $\mathrm{nm}$ to $600 \mathrm{~nm}$, and quantified at $450 \mathrm{~nm}$ (for $\beta$-apo8'-carotenal, $\beta$-carotene), $350 \mathrm{~nm}$ (for phytofluene) and $290 \mathrm{~nm}$ (for phytoene). $\beta$-carotene and $\beta$-apo8'-carotenal were identified by co-elution of standards. The others (phytoene, and phytofluene), and especially $\beta$-carotene isomers, were tentatively identified according to their UV spectrum and quantified as equivalent of $\beta$-carotene and corrected according to their extinction coefficient. Quantification was performed relative to the peak area of the internal standard ( $\beta$-apo8'-carotenal). Response factors were calculated for $\beta$-carotene from standard solutions. The results are expressed equivalent $\beta$-carotene using its response factor. Carotenoid levels were expressed in $\mathrm{mg} \mathrm{kg}^{-1}$ of fresh weight.

\section{Statistical analysis}

Results are presented as mean values. Two-way analysis of variance (ANOVA) by Fisher's test (F) was used to compare the means and performed using the X1 Stat package of Microsoft Excel. Difference was considered significant at $\mathrm{P} \leq 0.05$. 


\section{Results and discussion}

\section{Global characterization of apricot after canning and storage by mid-infrared spectroscopy (MIRS)}

For each variety and each processing condition, samples (fruits without syrup) were analysed by MIRS reflecting information on changes of biochemical composition especially for major metabolites such as sugars and organic acids (Bureau et al., 2009a). ANOVA performed on spectral data allowed to classify factors, here cultivar and cooking conditions, according to their effect on apricot spectral data. The Fisher values (F) was higher for cultivar $(\mathrm{F}=180)$ than for cooking conditions $(\mathrm{F}=60)$ (results not shown). ANOVA allowed also identifying the most informative spectral regions according to the studied effects, which were in this study between 1500 and $1000 \mathrm{~cm}^{-1}$ for the cultivar and between 1800 and $1500 \mathrm{~cm}^{-1}$ for the cooking conditions. In order to highlight the effect of the cooking conditions, a Principal Component Analysis (PCA) was performed on the second region ranging from 1800 and $1500 \mathrm{~cm}^{-1}$ (Figure 1A). PC1 represented $84.3 \%$ of the total variability whereas PC2 only 7.1\%. The main variations were then observed on the PC1. 'Goldrich' and 'Iranien' were clearly separated on the PC1. 'Hargrand' and 'Orangered ${ }^{\circledR}$ Bhart' appeared to be overlapped on PC1 (84.3\% variation) but not on PC2 (7.1\% variation). Inside each cultivar group, cooking conditions always respected the same trend: on the left, fresh and domestic cooking samples (F and D) and on the right, canned apricot with 1 day and 2 months of storage (C0 and C2). The first and second eigenvectors (Figure 1, B and C) showed negative peaks at 1717 and $1636 \mathrm{~cm}^{-1}$ for the first eigenvectors and positive peaks at 1724 and $1589 \mathrm{~cm}^{-1}$ for the second one. The sample discrimination seemed to be in relation with organic acid and water content. Indeed, peaks at 1717,1724 and $1589 \mathrm{~cm}^{-1}$ could be attributed to the $\mathrm{C}=\mathrm{O}$ fonction of carboxylic acid with absorption in the range $1740-1660 \mathrm{~cm}^{-1}$ and when ionisated characterized by 2 bands with one between 1630-1550 $\mathrm{cm}^{-1}$ (Coates, 2000; Bertrand \& Dufour, 2000). 
Moreover the deformation of $\mathrm{O}-\mathrm{H}$ (bending scissoring) provides a band with a maximum at $1636 \mathrm{~cm}^{-1}$ in our conditions.

\section{Sugar and acid}

\section{Sugar and acid determinations}

Sucrose was the main sugar in fresh apricots accounting for 37 to $77 \%$ of total sugars, followed by glucose (13-33\%) and fructose (9-39\%) except in 'Iranien' cultivar where fructose was the second main sugar (Table 1). Sucrose concentrations were in accordance with results from other studies (Schmitzer, Slatnar, Mikulic-Petkovsek, Veberic, Krska, \& Stampar, 2010; Caliskan, Bayazit, \& Sumbul, 2012; Aubert \& Chanforan, 2007; Bureau et al., $2009 \mathrm{~b})$ with reported concentration ranging from 12 to $110 \mathrm{~g} \mathrm{~kg}^{-1} \mathrm{FW}$. Glucose and fructose concentrations ranges measured by Aubert \& Chanforan (2007), Bureau et al. (2009b), Schmitzer et al. (2010), and Caliskan et al. (2012), were from 6.0 to $54.6 \mathrm{~g} \mathrm{~kg}^{-1} \mathrm{FW}$ and from 1.0 to $44.2 \mathrm{~g} \mathrm{~kg}^{-1} \mathrm{FW}$, respectively in agreement with the present data.

The mean levels of malic and citric acid concentrations in fresh apricots were quite similar, ranging respectively from 3.8 to $10.7 \mathrm{~g} \mathrm{~kg}^{-1} \mathrm{FW}$ and to 5.5 to $13 \mathrm{~g} \mathrm{~kg}^{-1} \mathrm{FW}$, in agreement with those measured by Aubert \& Chanforan (2007), Schmitzer et al. (2010) and Bureau et al. (2009b) with 'Orangered ${ }^{\circledR}$ Bhart' and 'Iranien' the less acid and 'Hargrand' and 'Goldrich' the more acidic cultivars. It was to note that usually the 'Iranien' acid contents are lower than those of 'Orangered® Bhart' (Ribas-Agusti et al., 2017). This difference was due to the fact that 'Iranian' was less mature.

\section{Canning effect}

Except for 'Hargrand', a significant increased of sucrose concentration was observed for industrial canning. In contrast, for domestic cooking, except for 'Goldrich', sucrose 
concentration decreased. The increase observed could be due to an equilibration of the fruit and syrup sucrose concentration consecutive to a softening of the fruit tissue. For glucose and fructose all cases were observed, their concentrations in the processed fruits may be close to, lower, or higher than in the fresh fruit, again probably due to an equilibration of the concentrations between the fruit and the syrup.

Pasteurization of fresh apricots significantly affected the organic acid concentrations (Table 1), but with different trends. Industrial processing caused a significantly higher loss of organic acids when compared to domestic cooking, for which organic acid concentrations remained close to those observed in fresh fruit, in accordance with MIRS. Loss by leaching from fruit to syrup was more favored by the industrial treatment that induced a stronger softening of the flesh (Supplementary data S1). Moreover, the observed trends may also result from a kinetic effect. After domestic cooking the separation between the fruit halves and the liquid took place very quickly after the cooking, whereas in the case of industrial treatment the separation between the solid and the liquid was done one day after the cooking of the cans.

\section{Storage effect}

A significant increase of glucose and fructose concentrations was observed with storage except for 'Iranien'. This could be due to a syrup sucrose hydrolysis during storage due to low syrup pH (below 4.0, data not shown). In fact samples showed a slight decrease in sucrose with storage but it was not significant.

The concentration of malic acid, but not citric acid, decreased significantly after two months of storage. The fact that malic acid decreased during storage while citric acid was stable could be due to their tissue distribution. While malic aid is located preferentially in the pulp, citric acid has a subepidermal distribution (Lichou \& Jay, 2012). The localization of the 
malic acid would thus promote its leaching in the syrup as opposed to the citric hence the differences observed during storage for both acids.

\section{Phenolic compounds}

\section{Phenolic profile}

Four major phenolic groups with a total of 9 identified individual compounds were quantified (Table 2). Phenolic compounds included flavan-3-ols ((+)-catechin and (-)epicatechin (monomer) and procyanidins (polymers)), two hydroxycinnamic acids (3-Ocaffeoylquinic and 5-O-caffeoylquinic acids), two flavonols (quercetin-3-O-rutinoside, and 3-O-glucoside) and two anthocyanins (cyanidin-3-O-rutinoside and cyanidin-3-O-glucoside). These groups coincide with those found previously in other stone fruits (peach and nectarine) (Tomas-Barberan, Gil, Cremin, Waterhouse, Hess-Pierce, \& Kader, 2001; Tavarini et al., 2011) and apricots (Ruiz, Egea, Gil, \& Tomas-Barberan, F.A. 2005a).

For fresh fruits, phenolic levels ranged between 406 and $2013 \mathrm{mg} \mathrm{kg}^{-1} \mathrm{FW}$. Overall, these quantities are noticeably higher than previously published data (Ruiz et al., 2005a). Ruiz et al., (2005a) found that total phenolic content, quantified as the sum of the individual compounds identified by HPLC, between 326 and $1600 \mathrm{mg} \mathrm{kg}^{-1} \mathrm{FW}$ of edible tissue. Differences observed may be due to the cultivar analyzed and to the thiolysis-HPLC method that allows a better estimation of polymerized proanthocyanidins. These compounds are usually underestimated when alcoholic or hydro-alcoholic extractions are used because most of them are not extracted (Ruiz et al., 2005a). Moreover, after extraction, their estimation by direct HPLC remains incomplete because polymeric forms do not give well-resolved peaks on chromatograms. Therefore, at best, only oligomers have been quantified by direct HPLC analyses (Ruiz et al., 2005a). 
Among the four major groups, procyanidins were the predominant class. The structure of apricot procyanidin showed a great homogeneity for all cultivar on the basis of the nature of the constitutive flavan-3-ol units. (-)-Epicatechin was always the predominant constitutive unit, accounting for more than $85 \%$ of total units for all cultivars with a small proportion of (+)-catechin detected only as terminal units. The proportions of (-)-epicatechin and (+)catechin as terminal units were noticeably variables from one cultivar to another. Except 'Goldrich' cultivar (8\% terminal (+)-catechin and 14\% terminal (-)-epicatechin), terminal (+)catechin was always predominant i.e. 9\% terminal (+)-catechin and 1\% terminal (-)epicatechin for 'Hargrand', 11\% terminal (+)-catechin and 8\% terminal (-)-epicatechin for 'Orangered ${ }^{\circledR}$ Bhart' and $13 \%$ terminal (+)-catechin and 3\% terminal (-)-epicatechin for 'Iranien'. These percentages may be slightly overestimated because of the epimerization reaction occurring under the conditions of thiolysis. Procyanidins' average degrees of polymerisation (DPn) ranged between 4.7 and 10.7 and were close to those of apple procyanidins (Guyot et al., 2001; Le Bourvellec et al., 2011). The procyanidins' DPn determined in this study were higher than those calculated from normal-phase HPLC-DAD by Ruiz et al. (2005a). The only flavan-3-ol monomers detected were (+)-catechin and (-)epicatechin. Hydroxycinnamic acids represented the second phenolic class. Except in 'Goldrich' cultivar, the amount of 5-O-caffeoylquinic acid was higher than that of 3-Ocaffeoylquinic acid. The occurrence of quercetin-3-O-rutinoside and quercetin-3-O-glucoside in apricots was reported in (Ruiz et al., 2005a ; Campbell, Merwin, \& Padilla-Zakour, 2013) as well as other flavonols derivatives. Cyanidin-3-O-glucoside and cyanidin-3-O-rutinoside were the only two anthocyanin detected in 'Orangered ${ }^{\circledR}$ Bhart' cultivar (Ruiz et al., 2005a). However, Bureau, Renard, Reich, Ginies, \& Audergon, (2009c) detected three anthocyanins in red apricot fruits, the major compound being cyanidin-3-O-rutinoside, and two minor compounds cyanidin-3-O-glucoside and peonidin-3-O-rutinoside. The anthocyanins, despite 
being in low concentrations (32 $\mathrm{mg} \mathrm{kg}^{-1} \mathrm{FW}$ ) had a clear impact in apricot skin color, providing a red blush. Among the analyzed cultivars, 3 have no supracolor while only 'Orangered $®$ Bhart' has one, so the results are consistent with the visual characterization.

All the concentrations of monomeric phenolic compound (flavan-3-ol monomers, hydroxycinnamic acids, flavonols and anthocyanins) are consistent with previous works (Campbell et al., 2013) which further showed a wide variation in the phenolic content of different cultivars (Campbell et al., 2013; Ruiz et al., 2005a).

\section{Canning effect}

Pasteurization of fresh apricots significantly affected the phenolic compound concentrations (Table 2), as demonstrated on various fruits (Asami, Hong, Barrett, \& Mitchell A.E. 2003; Chaovanalikit \& Wrolstad, 2004a; Brownmiller et al., 2009). Industrial thermal processing caused a significant higher loss of total phenolic compounds from $13 \%$ (in 'Hargrand') to $47 \%$ (in 'Iranien') when compared to domestic cooking from $2 \%$ (in 'Hargrand') to $33 \%$ (in 'Orangered ${ }^{\circledR}$ Bhart'), which may be related to the different temperature levels. Moreover, higher temperatures may increase membranes permeability facilitating leaching (Jimenez, Martinez-Tomé, Romojaro, Murcia, 2008; Chaovanalikit \& Wrolstad, 2004a). Asami et al. (2003) report a 20\% reduction in total phenolics after pasteurization of peach samples at $110^{\circ} \mathrm{C}$. Decreases in total phenolic content after canning of blueberry or cherry products have also been reported (Chaovanalikit \& Wrolstad, 2004a; Brownmiller et al., 2009).

Retention of polyphenol in canned apricots was higher for flavan-3-ols. Processing, industrial and domestic, resulted in $2.4 \%$ (in 'Hargrand') to $44 \%$ (in 'Iranien') loss in procyanidins, but the type of processing had no significant effect on procyanidin losses. Procyanidin's DPn significantly increased from fresh fruit to canned products. Procyanidins are known to form complexes with food macromolecules (proteins and carbohydrates) (Le 
Bourvellec \& Renard, 2012). Especially, procyanidins with high degree of polymerization are adsorbed onto cell walls by physico-chemical interactions. So the increase observed could be due to leaching of procyanidins of low molecular weight into the syrup during cooking and retention of procyanidins of high molecular weight within fruit tissues. Renard (2005) also observed this phenomenon during pear cooking. Flavan-3-ol monomers were significantly decreased after processing, and notably after industrial cooking.

Hydroxycinnamic acids, 3-O-caffeoylquinic acid and 5-O-caffeoylquinic acid, were significantly lost from apricot halves after cooking (Table 2) and this loss significantly differed between the two processes. Lower losses were observed after domestic cooking. Except in 'Iranien' cultivar, an increased was observed for flavonols after domestic cooking. This might be due to a matrix softening effect, which increased the extraction efficiency of flavonols in the softened peel, as in most fruit flavonols are highly concentrated in the peel, resulting in a higher concentration with respect to the raw material. However, after industrial cooking a decrease in flavonol concentrations was observed, except for 'Hargrand'. The flavonol effects observed with industrial cooking may be due to a negative balance between extractability in the softened fruits (Supplementary material S1) and a loss by degradation and/or leaching.

'Orangered ${ }^{\circledR}$ Bhart' anthocyanins were significantly altered by the heat treatment

(Table 2), but there was no difference between processes. Heating also decreases anthocyanin concentrations in nectarines but not in cherries, peaches and plums (Chaovanalikit \& Wolstrad, 2004b; Leong \& Oey, 2012).

\section{Storage effect}

The 2 months storage did not provide a significant loss of total phenolic compounds; this was mainly due to the fact that procyanidins were stable during storage (Table 2). This agree with the study of Jimenez et al., (2008) who found no changes in the different 
antioxidant activities assays from 1 to 150 day of storage of canned apricots. It should be pointed out, however, that 'Iranien' and 'Orangered ${ }^{\circledR}$ Bhart, the less concentrated cultivars, were those which had the most losses, even if it was not significant.

While flavan-3-ol monomer and hydroxycinnamic acid concentrations decreased significantly after storage, flavonol glycosides differed in their responses: quercetin-3-Oglucoside concentrations being lower, close to, or higher than in the fresh fruit, in contrast to quercetin-3-O-rutinoside. Moreover, the flavonol glycosides response to storage was cultivar dependent. For anthocyanins, significant losses after two months of storage were observed as in the case of canned cherries (Chaovanalikit \& Wolstrad, 2004b).

\section{Balance between degradation and leaching}

In order to estimate the proportion of losses due to thermal degradation or migration from the food matrix to the syrup, the levels of phenolic compounds were calculated on a percan basis (weights of fruit and syrup) and compared to the content calculated for fresh apricots (fruit weight, 100\%) (Figure 2). (+)-Catechin losses observed were mainly due to degradation induced by industrial processing and storage in contrast to (-)-epicatechin which was both degraded and leached into the syrup (Figure 2A and B). Industrial processing which increased the matrix softening effect compared to domestic cooking (Supplementary material S1) favored the leaching into the fruit syrup. The apparent susceptibility of (-)-epicatechin to leaching into the syrup compared to (+)-catechin could be attributed to a mechanism of epimerization of (-) epicatechin to (+)-catechin which might occured in these heated conditions (Vidal, Cartalade, Souquet, Fulcrand \& Cheynier, 2002 ; Guyot, Doco, Souquet, Moutounet \& Drilleau, 1997). Procyanidins were mainly degraded by processing (Figure 2C), except in the case of 'Hargrand' and 'Orangered ${ }^{\circledR}$ Bhart' cultivars for which a leaching into the syrup was also observed. Their susceptibility to degradation was also cultivar dependent and followed the same trend as the monomeric flavan-3-ols. Changes in 3- and 5- 
caffeoylquinic acids (Figure 2D and E) contents resulted from thermal degradation and leaching favored by industrial processing except in the case of 'Iranien' cultivar. Anthocyanins were also prone to thermal degradation and leaching (Figure 2F). Changes in flavonols upon cooking resulted in higher content with respect with to the raw material due to a food matrix destructuring effect. However, the softening of the food matrix structure was not correlated to the extractability increase. For example 'Goldrich' was the cultivar for which the softening was the strongest (Supplementary material S1) but it was not the one for which there was the highest increase of the extractability.

In view of these results, for total polyphenol contents, the cultivar susceptibility to leaching and degradation was in the following order: 'Iranien' = 'Orangered ${ }^{\circledR}$ Bhart' > 'Goldrich'> 'Hargrand'. It appeared that this result was associated with levels of TPP that were Orangered ${ }^{\circledR}$ Bhart'< 'Iranien'< 'Goldrich'< 'Hargrand'. The less the cultivars were concentrated in polyphenols the more susceptible they were to degradation and leaching.

\section{Carotenoids}

Four different carotenoids were identified in fresh and cooked apricots (Table 4). Carotenoid analysis was not performed on the syrups because Campbell \& Padilla-Zakour (2013) have shown that leaching of apricot carotenoid after canning was minimal $(<1 \%)$. Because of the general insolubility of carotenoids in water, the presence of this compound in syrup was though to be largely due to dispersed fruit fragment.

The total carotenoid contents varied from $7.8 \mathrm{mg} \mathrm{kg}^{-1} \mathrm{FW}$ in 'Iranien' to $108.9 \mathrm{mg} \mathrm{kg}^{-1}$ FW in 'Hargrand'. On the whole, mean values of total carotenoids were similar to those reported by Ruiz, Egea, Tomas-Barberan, \& Gil, (2005b) (15-165 $\left.\mathrm{mg} \mathrm{kg}^{-1} \mathrm{FW}\right)$ for 37 apricot cultivars and hybrids, except for 'Iranien' which showed very low carotenoid contents (in accordance with low color values, data not shown). 
In agreement with other published results (Leccese et al., 2010; Ruiz et al., 2005b; Kurz, Carle, \& Schieber, 2008; Campbell et al., 2013), the most abundant carotenoid in apricot fruit depends on the cultivar, trans- $\beta$-carotene in Goldrich and Orangered $®$ Bhart, phytoene on 'Hargrand', and phytofluene on 'Iranien'.

Microscopic investigations revealed that within the chromoplast, $\beta$-carotene can be either in a crystalline form or partially solubilized in lipid droplets as a function of fruits and vegetables (Pénicaud, Achir, Dhuique-Mayer, Dornier \& Bohuon, 2011). It seemed that, in apricot, $\beta$-carotene was partially solubilized in lipid droplets, and a portion of cis- $\beta$-carotene naturally occurs (Kurz et al., 2008). A cis- $\beta$-carotene isomer was detected in fresh apricots (Table 4). According to our chromatographic conditions, UV/vis spectral data and literature data (Carle, \& Schieber, 2005 ; Kurz et al. 2008), therefore, we assumed that the cis isomer of $\beta$-carotene detected in apricots was the 13-cis-isomer. The physical state of the carotenoids present in apricots could be an important factor for the stability of $\beta$-carotene both during the process and during the storage.

\section{Canning effect}

Concentrations of total carotenoids exhibited no significant change after heat processing (Table 3). In fact, samples showed a slight increase in total carotenoids with canning. This might be due to an increased of extraction efficiency in the softened fruits, disruption of caroteno-protein complexes, and/or inactivation of oxidizing enzymes (Lessin et al., 1997). Among the four carotenoids analyzed, only cis- $\beta$-carotene was significantly increased after heat processing. Several studies have reported an increase in cis-isomers in vegetables subjected to thermal processes (Schieber \& Carle, 2005; Lessin et al., 1997). In particular, thermal treatment is known to cause the formation of the 13-cis-isomer (Schieber $\&$ Carle, 2005). The assumption that the cis isomer of $\beta$-carotene detected in our samples was the 13 -cis-isomer was corroborated by the fact that the cis- $\beta$-carotene detected in fresh apricot 
was significantly increased after heat processing and that no new peaks were visible on the HPLC chromatograms. The physical state of carotenes can be considered as the most critical factor leading to isomerization (Marx, Stuparic, Schieber \& Carle, 2003). Hence, The increased of cis- $\beta$-carotene could also be attributed to the partial dissolution of crystalline carotene present in the intact apricot in lipid droplets (Kurz et al., 2008) as trans-cisisomerization is facilitated when carotenoids are dissolved, whereas crystalline carotenoids tend to be more stable (Schieber \& Carle, 2005 ; Pénicaud et al., 2011).

Significant lower contents of cis- $\beta$-carotene were obtained after domestic cooking than canning, probably due to lower temperature of processing.

\section{Storage effect}

Total carotenoid compounds significantly decrease over the storage period. Campbell \& Padilla-Zakour (2013) have also shown a decrease of carotenoids after 6 months of storage. Carotenoids from kiwifruit puree tend also to be significantly reduced over time (BenllochTinoco, Kaulmann, Corte-Real, Rodrigo, Martínez-Navarrete, \& Bohn, 2015). Carotenoid degradation during storage might be due to oxidation reactions leading to the formation of low molecular weight epoxicarotenoids and apocarotenoids (Oliveira et al., 2012), however no new peaks were visible on the HPLC chromatograms after storage. Among carotenoids, trans- $\beta$-carotene concentrations were not modified by storage. Tomato paste $\beta$-carotene and lycopene remained also constant through 12 months of storage (Koh et al., 2011). Overall, the discrepancy with data in the literature might be attributable to the great variability of carotenoid stability in different food matrices (Lee \& Coates, 1999). Moreover, the fact that trans- $\beta$-carotene concentrations were not modified by storage could also be attributed to their physical state as crystalline carotenoids tend to be more stable than dissolved carotenoids (Schieber \& Carle, 2005). Moreover, it seemed also that isomerization of $\beta$-carotene was a prerequisite for oxidation degradation (Pénicaud et al., 2011). 


\section{Conclusions}

The effect of cooking on polyphenol and carotenoid concentrations depends on the processing parameters, the structure of the food matrix, the chemical nature and the physical state of the phytonutrients. Carotenoids were more stable than phenolic compounds upon thermal treatments. Thus, domestic cooking ensured better preservation of polyphenols than industrial processing: due to lower temperature used, thermal degradation was limited. Finally, it appeared that the polyphenol losses observed were largely due to initial thermal degradation and diffusion in the syrup, but they were relatively stable during storage. However, carotenoids showed a different behavior, thermal treatment induced increased extraction efficiency leading to an apparent increase upon processing but they were degraded during storage.

Moreover, it seemed that the stability of carotenoids could mainly be attributed to their physical state, i.e. the crystalline form. The physical appearance of carotenoids appears to be an important factor in their stability during the processes. Thus, it appeared that in apricot, within the chromoplast, $\beta$-carotene could be in a crystalline form, partially solubilized in lipid droplets and a portion of cis- $\beta$-carotene naturally occurred. During processing, the crystalline form remained stable and the form partially solubilized in lipid droplets isomerized resulting in a stabilization of trans- $\beta$-carotene and an increased in cis- $\beta$-carotene. During storage, it appeared that the crystalline form remained stable as evidenced by trans- $\beta$-carotene contents after 2 months of storage whereas the cis-isomer forms were reduced probably due to degradation by oxidation.

The content of polyphenols and carotenoids after processing and storage is a net result of a combined increase in phytonutrient extractability, and a loss by degradation and leaching. It should also be noted that processing preserved a good part of the potential of the fruit, which is of interest to the consumer. 


\section{Acknowledgements}

The authors thank Line Touloumet, Marielle Bogé, Caroline Garcia, Alain Blanc and Guy Clauzel for their technical help.

This work was financed by the Agence Nationale de la Recherche under the project ILLIAD (ANR-11-ALID-0006)

\section{References}

Asami, D.K., Hong, Y.J., Barrett, D.M., \& Mitchell A.E. (2003). Processing induced changes in total phenolics and procyanidines in cligstone peaches. Journal of the Science of Food and Agriculture, 83, 56-63.

Aubert, C., \& Chanforan, C. (2007). Postharvest changes in physicochemical properties and volatile constituents of apricot (Prunus armeniaca L.) characterization of 28 cultivars. Journal of Agriculture and Food Chemistry, 55, 3074-3082.

Benlloch-Tinoco, M., Kaulmann, A., Corte-Real, J., Rodrigo, D., Martínez-Navarrete, N., \& Bohn, T. (2015). Chlorophylls and carotenoids of kiwifruit puree are affected similarly or less by microwave than by conventional heat processing and storage. Food Chemistry, 187, 254-262.

Bertrand, D., \& Dufour, E. (2000). La spectroscopie infrarouge et ses applications analytiques. Ed. Tec \& Doc, Paris, Londres, New York. 566 p.

Bureau, S., Ruiz D., Reich, M., Gouble B., Bertrand D., Audergon J.M., \& Renard C.M.G.C. (2009a). Rapid and non-destructive analysis of apricot fruit quality using FT-nearinfrared spectroscopy. Food Chemistry, 113, 1323-1328.

Bureau, S., Ruiz, D., Reich, M., Gouble, B., Bertrand, D., Audergon, J.M., \& Renard, C.M.G.C. (2009b). Application of ATR-FTIR for a rapid and simultaneous determination of sugar and organic acids in apricot fruit. Food Chemistry, 115, 1133-1140. 
Bureau, S., Renard, C.M.G.C, Reich, M, Ginies, C., \& Audergon, J.M. (2009c). change in anthocyanin concentrations in red apricot fruits during ripening. LWT-Food Science and Technology, 42, 372-377.

Bureau, S., Quilot, B., Signoret, V., Renaud, C., Maucourt, M., Bancel, D., \& Renard, C.M.G.C. (2013). Determination of the composition in sugars and organic acids in peach using mid-infrared spectroscopy: comparison of prediction results according to datasets and different reference methods. Analytical Chemistry, 2013, 85, 11312-11318.

Bureau, S., Mouhoubi, S., Touloumet, L., Garcia, C., Moreau, F., Bedouet, V., \& Renard, C.M.G.C. (2015). Are folates, carotenoids and vitamin C affected by cooking? Four domestic procedures are compared on a large diversity of frozen vegetables. LWT-Food Science and Technology, 64, 735-741.

Brownmiller, C., Howard, L.R., \& Prior, R.L. (2009). Processing and storage effects on procyaniidns composition and concentration of processed blueberry products. Journal of Agriculture and Food Chemistry, 57, 1896-1902.

Caliskan, O., Bayazit, S., \& Sumbul, A. (2012). Fruit quality and phytochemical attributes of some apricot (Prunus armeniaca L.) cultivars as affected by genotypes and seasons. Notulae Botanicae Horti Agrobotanic, 40, 284-294.

Campbell, O.E., Merwin, I.A., \& Padilla-Zakour, O.I. (2013). Characterization of the effect of maturity at harvest on the phenolic and carotenoid content of northeast USA Apricot (Prunus armeniaca) varieties. Journal of Agriculture and Food Chemistry, 61, 12700-12710.

Campbell, O.E., \& Padilla-Zakour, O.I. (2013). Phenolic and carotenoid composition of canned peaches (Prunus persica) and apricots (Prunus armeniaca) as affected by variety and peeling. Food Research International, 54, 448-455. 
Chaovanalikit, A., \& Wrolstrad, R.E. (2004a). Total anthocyanidins and total phenolics of fresh and processed cherries and their antioxydant properties. Journal of Food Science, 69, 67-72.

Chaovanalikit, A., \& Wrolstrad, R.E. (2004b). Anthocyanin and polyphenolic composition of fresh and prodessed cherries. Journal of Food Science, 69, 73-83.

Coates, J. (2000). Interpretation of Infrared Spectra, A Practical Approach. In R.A. Meyers (Ed.), Encyclopedia of Analytical Chemistry pp 10815-10837. Chichester : Wiley and Sons.

Gouble, B., Grotte, M., Reling, P., Reich, M., Bureau, S., Audergon, J.M., Clauzel, G., \& Albagnac, G. (2006). Comparison between ripening on trees and post-harvest evolution for apricot cultivars contrasting in their rate of ethylene production. Acta Horticulturae, 717, 333336.

Grotte, M., Cadot, Y., Poussier, A., Loonis, D., Piétri, E., Duprat, F., \& Barbeau, G., 2001. Détermination du degré de maturité des baies de raisin par des mesures physiques : aspects méthodologiques. Journal International des Sciences de la Vigne et du Vin, 35, 86-98.

Guyot, S., Marnet, N., \& Drilleau, J.-F. (2001). Thiolysis-HPLC characterization of apple procyanidins covering a large range of polymerization states. Journal of Agriculture and Food Chemistry, 49, 14-20.

Guyot, S., Doco, T., Souquet, J. M., Moutounet, M., \& Drilleau, J.F. (1997). Characterization of highly polymerized procyanidins in cider apple (Malus sylvestris var. kermerrien) skin and pulp. Phytochemistry, 44, 351-357.

Hong, Y.J., Barrett, D.M., \& Mitchell, A.E. (2004). Liquid chromatography/mass spectrometry investigation of the impact of thermal processing and storage on peach procyanidins. Journal of Agriculture and Food Chemistry, 52, 2366-2371. 
Jimenez, A.M., Martinez-Tomé, I.E., Romojaro, F., \& Murcia, M.A. (2008). Effect of industrial processing and storage on antioxidant activity of apricot (Prunus armeniaca v. bulida). European Food Research Technology, 227, 125-134.

Koh, E., Charoenprasert, S., \& Mitchell, A.E. (2011). Effects of industrial tomato paste processing on ascorbic acid, flavonoids and carotenoids and their stability over one-year storage. Journal of the Science of Food and Agriculture, 92, 23-28

Kurz, C., Carle, R., \& Schieber, A. (2008). HPLC-DAD-MS ${ }^{\mathrm{n}}$ characterization of carotenoids from apricots and pumpkins for the evolution of fruit product authenticity. Food Chemistry, 110, 522-530.

Leccese, A., Bureau, S., Reich, M., Renard, C.M.G.C., Audergon, J.M., Mennone, C., Bartolini, S., \& Viti, R. (2010). Pomological and nutraceutical properties in apricot fruits : cultivation systems and cold storage fruit management. Plant Food Hum. Nutr. 65, 112-120.

Lee, H. S., \& Coates, G. A. (1999). Thermal pasteurization effects on color of red grapefruit juices. Journal of Food Science, 64, 663-666.

Leong, S. Y., \& Oey, I. (2012). Effects of processing on anthocyanins, carotenoids and vitamin C in summer fruits and vegetables. Food Chemistry, 133, 1577-1587.

Lessin, W.J. Catigani, G.L., \& Schwartz S.J. (1997). Quantification of cis-trans isomers of Provitamin A carotenoids in fresh and processed frutis and vegetables. Journal of Agriculture and Food Chemistry, 45, 3728-3732.

Le Bourvellec, C., Bouzerzour, K., Ginies, C., Regis, S., Plé, Y., \& Renard, C.M.G.C. (2011). Phenolic and polysaccharide composition of applesauce is close to that of apple flesh. Journal of Food Composition and Analysis, 24, 537-547.

Le Bourvellec, C., \& Renard C.M.G.C. (2012). Interactions between polyphenols and macromolecules: quantification methods and mechanisms. Critical Review of Food Science and Nutrition, 53, 213-248. 
Lichou, J., \& Jay, M. (2012). Monogaphie abricot. Ed, Ctifl, Paris. 568 p.

Marx, M., Stuparic, M., Schieber, A, \& Carle, R. (2003). Effects of thermal processing on trans-cis-isomerization of $\beta$-carotene in carrot juices and carotene containing preparations. Food Chemistry, 83, 609-617.

Oliveira, A., Pintado, M., \& Almeida, D.P.F. (2012). Phytochemical composition and antioxydant activity of peach as affected by pasteurization and storage duration. LWT-Food Science and Technology, 49, 202-207.

Page, D., Van Stratum, E., Degrou, A. \& Renard, C.M.G.C. (2012). Kinetics of temperature increase during tomato processing modulate the bioaccessibility of lycopene. Food Chemistry, 135, 2462-2469.

Pénicaud, C., Achir, N., Dhuique-Mayer, C., Dornier, M., Bohuon, P. (2011). Degradation of beta-carotene during fruit and vegetable processing or storage: reaction mechanisms and kinetic aspects: a review. Fruits, 66, 417-440.

Renard, C. M. G. C. (2005). Effects of conventional boiling on the polyphenols and cell walls of pears. Journal of the Science of Food and Agriculture, 85, 310-318.

Ribas-Agusti, A., Gouble, B., Bureau, S., Maingonnat, J.F, Audergon, J.M., \& Renard, C.M.G.C. (2017). Towards the use of biochemical indicators in the raw fruit for improved texture of pasteurized apricots. Food Bioprocess Technolology, 10, 662-673.

Ruiz, D., Egea, J., Gil, M.I., \& Tomas-Barberan, F.A. (2005a). Characterization and quantification of phenolic compounds in new apricot (Prunus armeniaca L.) varieties. Journal of Agriculture and Food Chemistry, 53, 9544-9552.

Ruiz, D., Egea, J., Tomas-Barberan, F.A., \&Gil, M.I., (2005b). Carotenoids from new apricot (Prunus armeniaca L.) varieties and their relationship with flesh and skin color. Journal of Agriculture and Food Chemistry, 53, 6368-6374. 
Schieber, A., \& Carle, R. (2005). Occurrence of carotenoid cis-isomers in food: Technological, analytical, and nutritional implications. Trends in Food Science and Technology, 16, 416-422.

Schmitzer, V., Slatnar, A., Mikulic-Petkovsek, M., Veberic, R., Krska, B., \& Stampar, F. (2010). Comparative study of primary and secondary metabolites in apricot (Prunus armeniaca L.) cultivars. Journal of the Science of Food and Agriculture, 91, 860-866.

Tavarini, S., Gil, M.I., Tomas-Barberan, F.A., Buendia, B., Remorini, D., Massai, R., Degl'Innocenti, E., \& Guidi, L. (2011). Effects of water stress and rootstocks on fruit phenolic composition and physical/chemical quality in Suncrest peach. Annals of Applied Biology, 158, 226-233.

Terry, P., Giovannucci, E., Michels, K. B., Bergkvist, L., Hansen, H., Holmberg, L., \& Wolk, A. (2001). Fruit, vegetables, dietary fiber, and risk of colorectal cancer. Journal of the National Cancer Institute, 93, 525-533.

Tomas-Barberan, F.A., Gil, M.I., Cremin, P., Waterhouse, A.L., Hess-Pierce, B., \& Kader, A.A. (2001). HPLC-DAD-ESIMS analysis of phenolic compounds in nectarine, peaches, and plums. Journal of Agriculture and Food Chemistry, 49, 4748-4760.

Vidal, S., Cartalade, D., Souquet, J. M., Fulcrand, H., Cheynier, V. (2002). Changes in proanthocyanidin chain length in winelike model solutions. Journal of Agriculture and Food Chemistry, 50, 2261-2266. 


\section{Figure captions}

Figure 1: A. Principal Component Analysis (PCA) on MIR spectral data acquired on apricot purees. Fig. A. Plot of samples distribution according to PC1 and PC2 with the distinction of cultivars ('Hargrand', 'Iranien', 'Goldrich' and 'Orangered ${ }^{\circledR}$ Bhart') and cooking conditions: $\mathrm{F}$ for fresh before processing, D: domestic cooking, C0: canning after 1 day of storage and $\mathrm{C} 2$ : canning after 2 months. Fig. $\mathrm{B}$ and $\mathrm{C}$ eigenvectors 1 and 2 respectively.

Figure 2: Levels of phenolic content in a per-can basis compared to the initial entire fruit content expressed in percentage.

GD: ‘Goldrich', HG: ‘Hargrand', IR: 'Iranien’, OR: 'Orangered® Bhart', D: domestic cooking, $\mathrm{C} 0$ : canning after 1 day of storage and $\mathrm{C} 2$ : canning after 2 months of storage.

Black line: initial entire fruit content in percentage. $\mathbf{\square}$ : fruit content in percentage, $\sqsubset$ : syrup content in percentage. 
Fig 1:

A

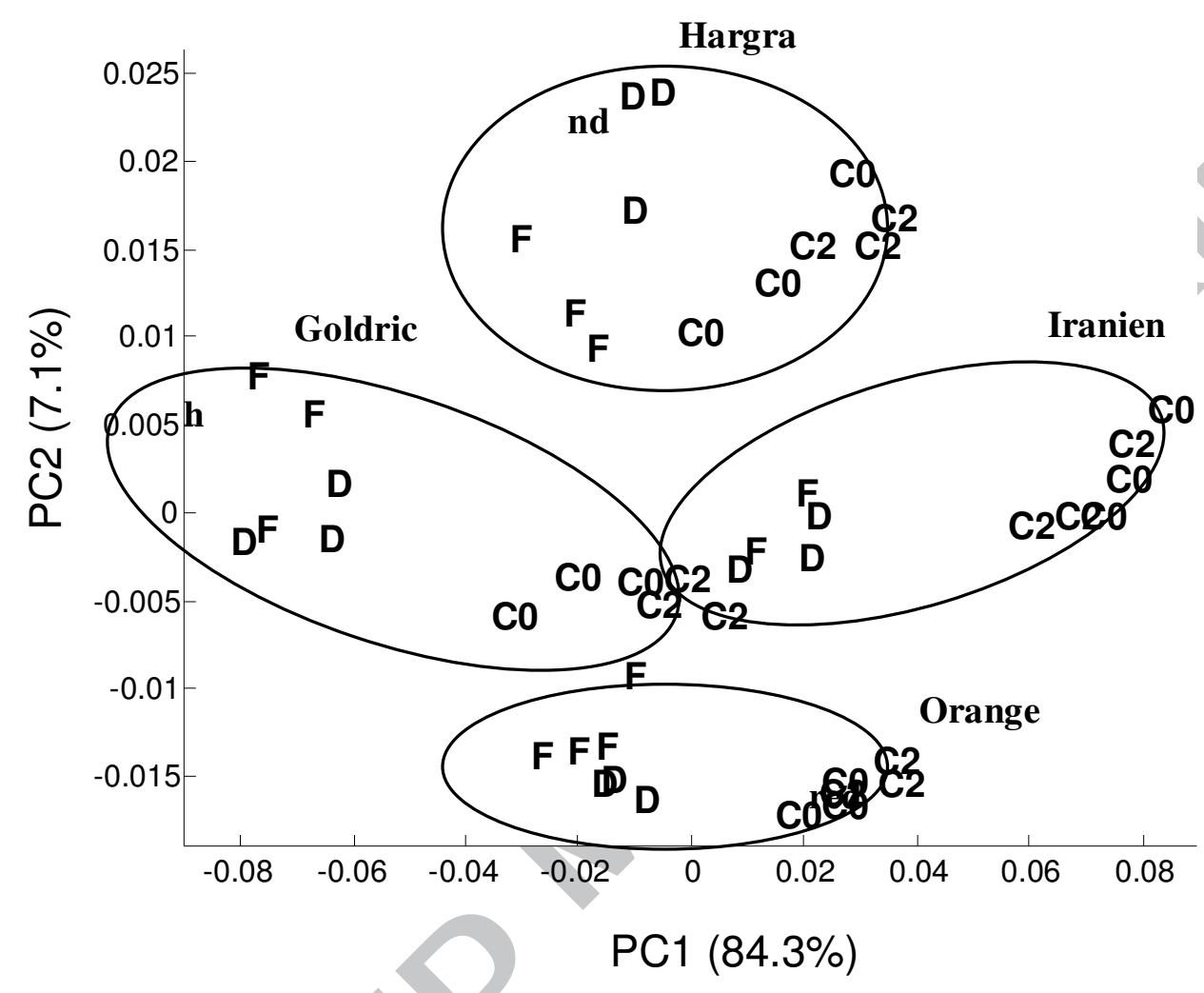


B

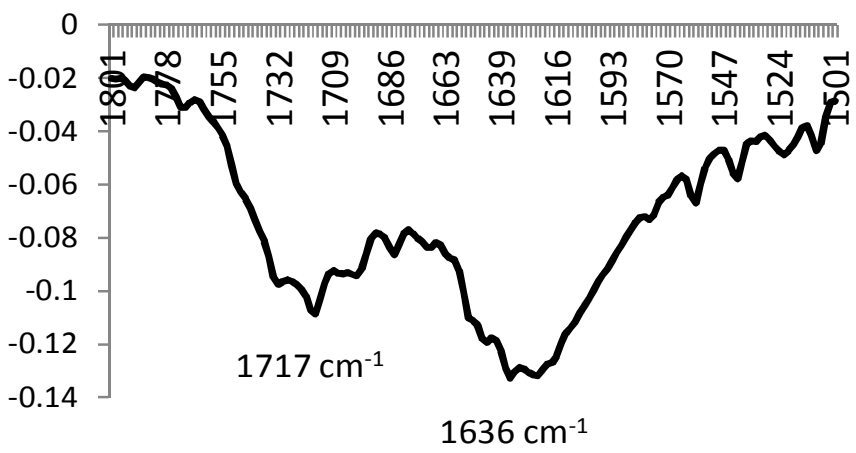

C

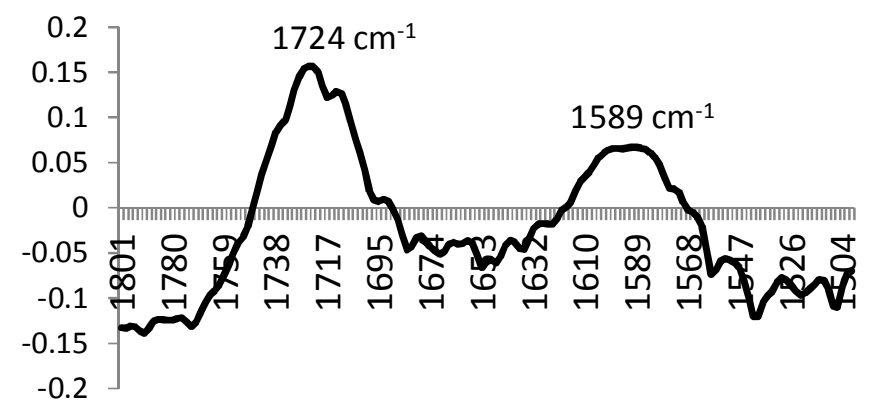

Fig 2 :
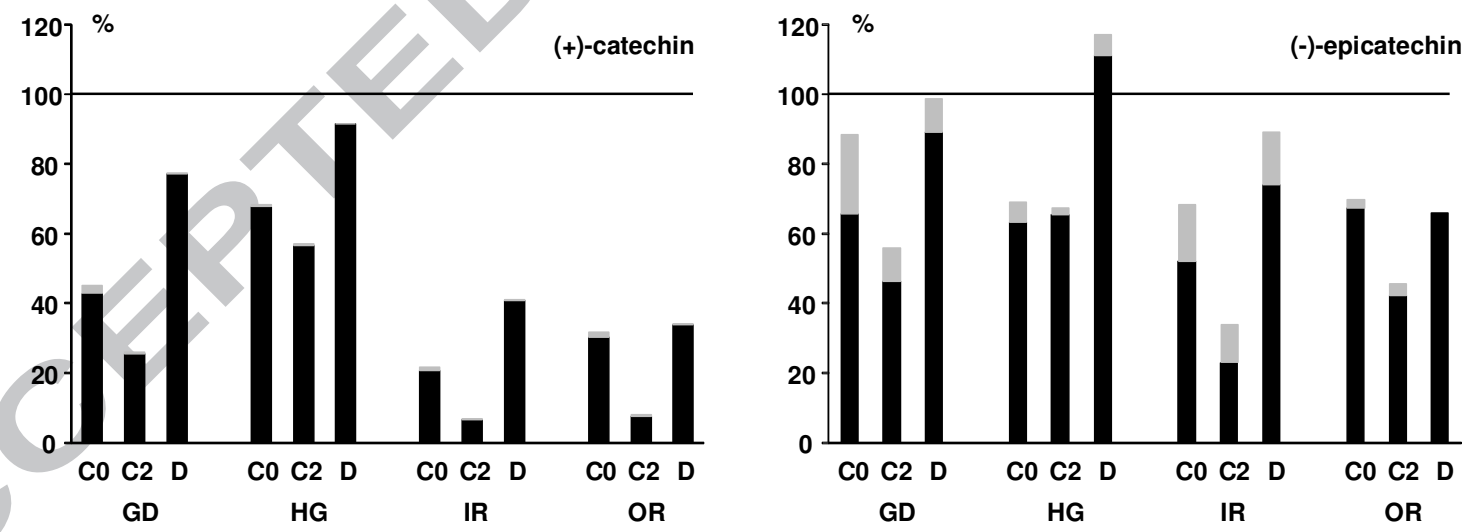

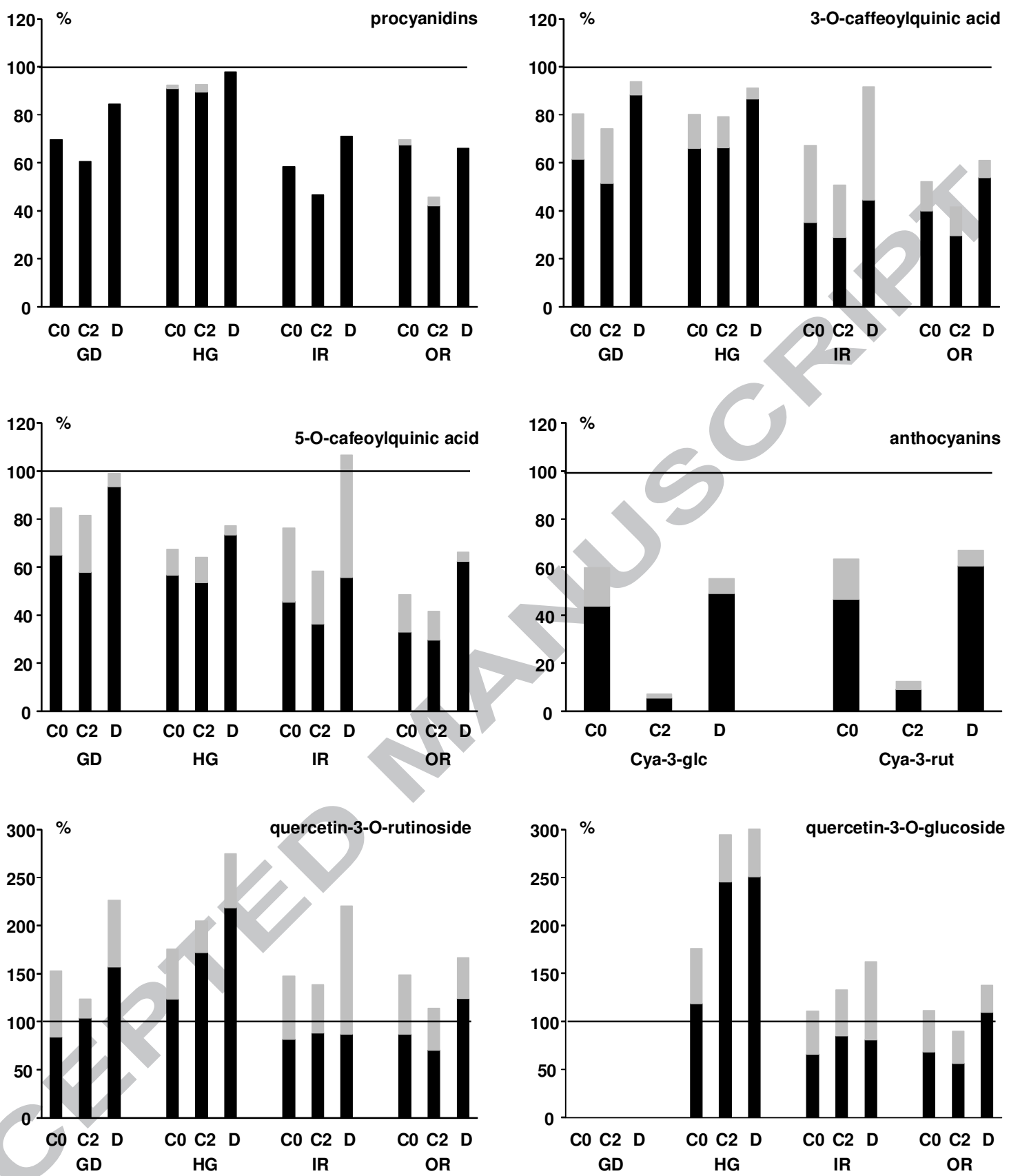
Table 1: Sugar and acid compositions $\left(\mathrm{g} \mathrm{kg}^{-1} \mathrm{FW}\right)$ in apricots as function of cultivars, processing and storage. 


\begin{tabular}{|c|c|c|c|c|c|c|c|}
\hline Cultivars & $\begin{array}{l}\text { Process } \\
\text { ing }\end{array}$ & St & $\begin{array}{l}\text { GI } \\
\text { ucose }\end{array}$ & ur & ucrose & $\begin{array}{l}\text { Ma } \\
\text { lic acid }\end{array}$ & $\begin{array}{l}\text { Citr } \\
\text { ic acid }\end{array}$ \\
\hline Iranien & fresh & & $\begin{array}{r}1 \\
9.8\end{array}$ & 8.2 & $\begin{array}{r}7 \\
1.1\end{array}$ & 3.8 & 6.2 \\
\hline Iranien & canned & $\begin{array}{l}1 \\
\text { day }\end{array}$ & $\begin{array}{r} \\
8.9\end{array}$ & $\begin{array}{r}1 \\
5.3\end{array}$ & 0.7 & 1.5 & 3.0 \\
\hline Iranien & canned & 6 days & $\begin{array}{r}1 \\
8.5\end{array}$ & 3.0 & $\begin{array}{r}8 \\
3.9\end{array}$ & 1.5 & 3.4 \\
\hline Iranien & $\begin{array}{l}\text { domest } \\
\text { ic cooking }\end{array}$ & day & $0.4^{2}$ & $\begin{array}{r}5 \\
3.3\end{array}$ & $\begin{array}{r}6 \\
6.0\end{array}$ & 3.3 & 5.6 \\
\hline Goldrich & fresh & & $\begin{array}{r}1 \\
4.8\end{array}$ & $\begin{array}{lll} & 8 . \\
& & \\
5 & & \end{array}$ & $\begin{array}{r}4 \\
\\
5.1\end{array}$ & $\begin{array}{l}10 . \\
7\end{array}$ & $\begin{array}{ll} & 13 . \\
& \\
0 & \end{array}$ \\
\hline Goldrich & canned & 1 & $\begin{array}{r}1 \\
5.5\end{array}$ & $\begin{array}{r}1 \\
1.4\end{array}$ & $\begin{array}{r}7 \\
0.5\end{array}$ & 6.8 & 6.7 \\
\hline Goldrich & canned & 6 & $\begin{array}{r}2 \\
1.2\end{array}$ & $\begin{array}{rr} & 3 \\
9.2 & \end{array}$ & $\begin{array}{r}6 \\
6.0\end{array}$ & 5.7 & 7.4 \\
\hline Goldrich & $\begin{array}{l}\text { domest } \\
\text { ic cooking }\end{array}$ & 0 & $\begin{array}{r} \\
2.7\end{array}$ & $\begin{array}{ll} & 8 . \\
0 & \end{array}$ & $\begin{array}{r}4 \\
9.9\end{array}$ & $\begin{array}{l}10 . \\
3\end{array}$ & $\begin{array}{ll} & 10 . \\
0 & \end{array}$ \\
\hline $\begin{array}{l}\text { Orangered }^{\circledR} \\
\text { Bhart }\end{array}$ & fresh & & $\begin{array}{r}2 \\
0.5\end{array}$ & $\begin{array}{ll} & 9 . \\
& \\
0 & \end{array}$ & $\begin{array}{r}4 \\
5.5\end{array}$ & 4.0 & 5.5 \\
\hline Orangered $^{\circledR}$ & canned & 1 & 1 & 7. & 6 & 2.2 & 2.2 \\
\hline
\end{tabular}




\section{ACCEPTED MANUSCRIPT}

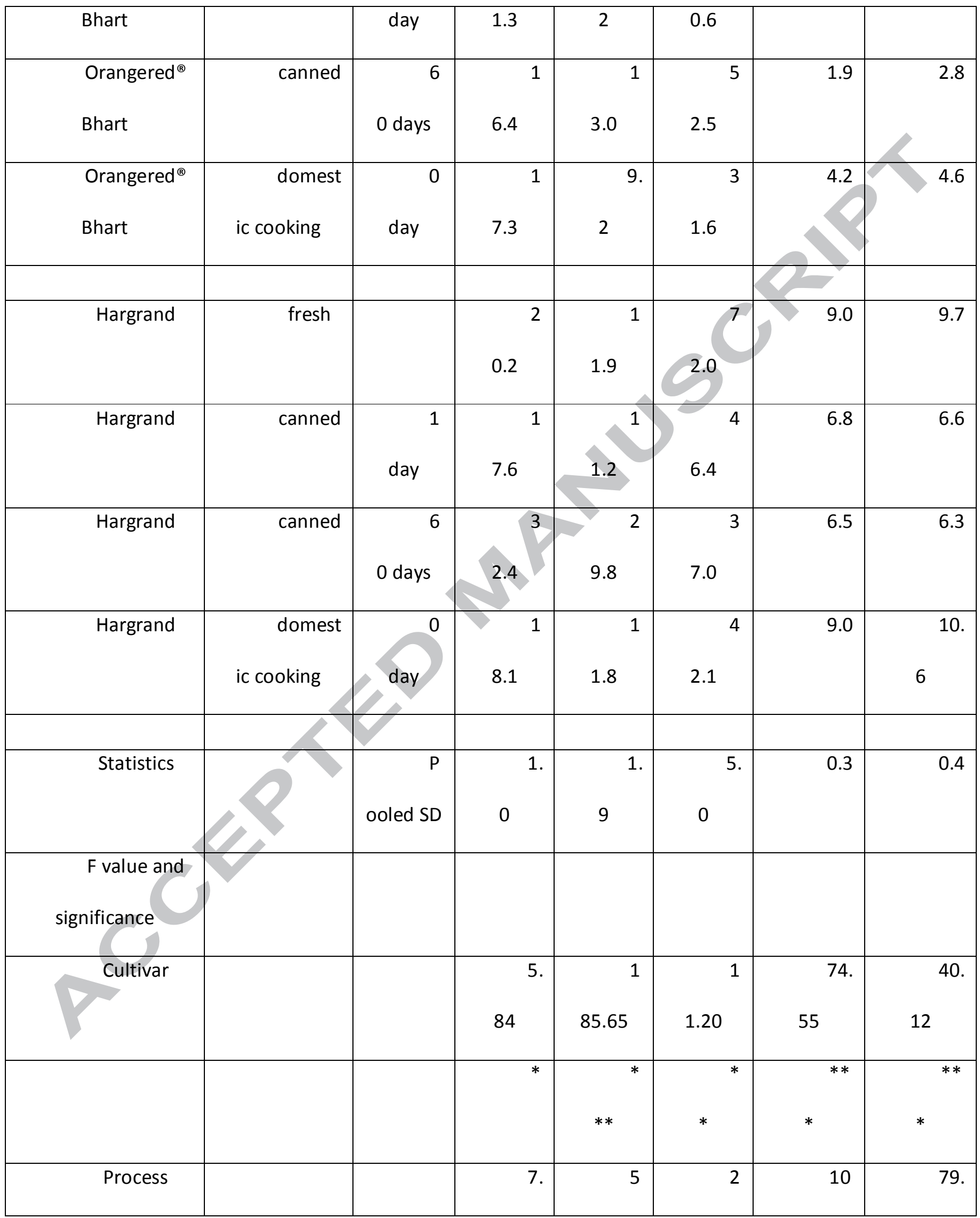




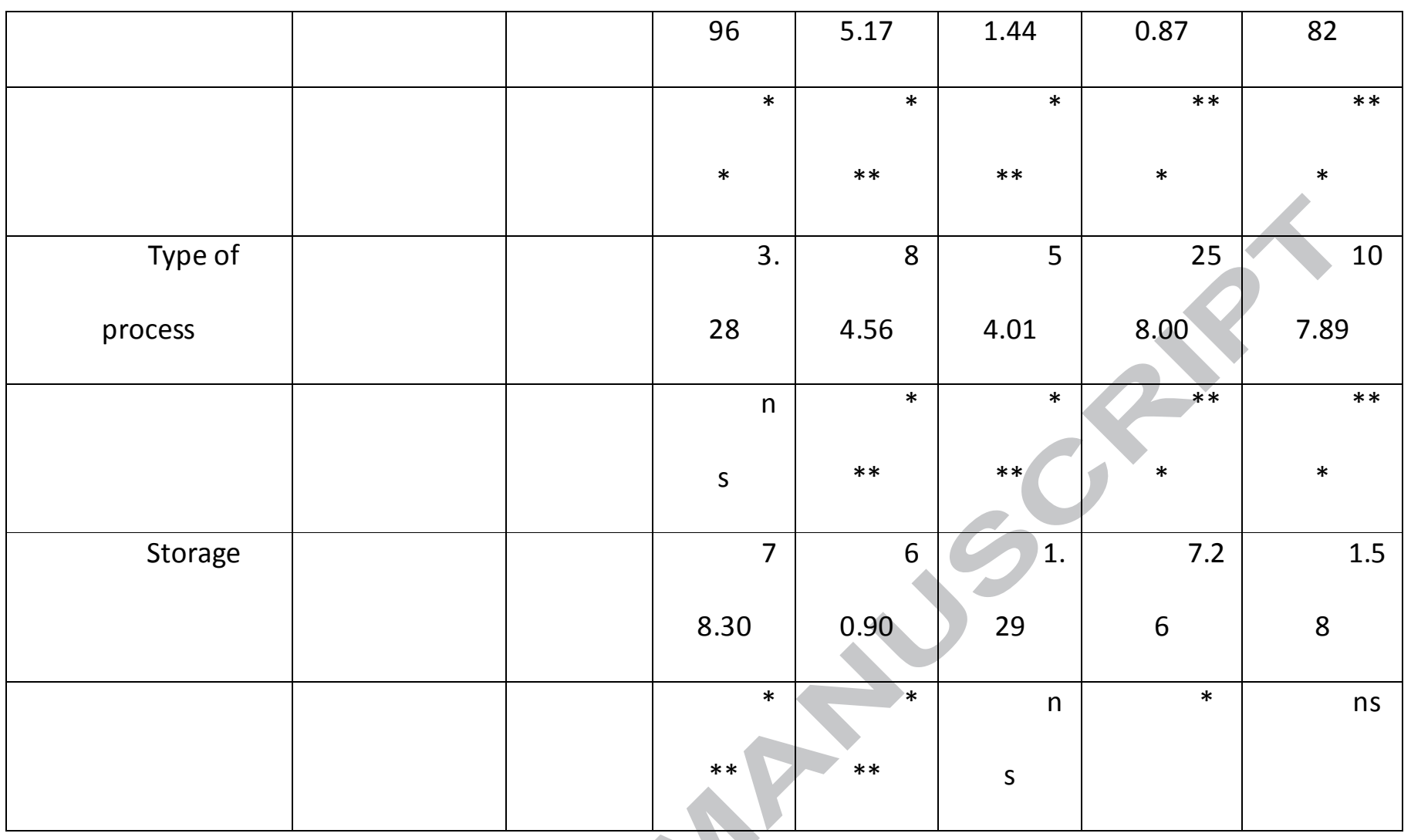

Pooled SD : pool standard deviation $\mathrm{ddl}=32$, ns (non significant), * $(\mathrm{P} \leq 0.05), * *(\mathrm{P} \leq 0.01), * * *(\mathrm{P} \leq 0.001)$.

Values are means of 3 replicates. 


\section{ACCEPTED MANUSCRIPT}

Table 2: Phenolic composition $\left(\mathrm{mg} \mathrm{kg}^{-1} \mathrm{FW}\right)$ in apricots as function of cultivars, processing and storage.

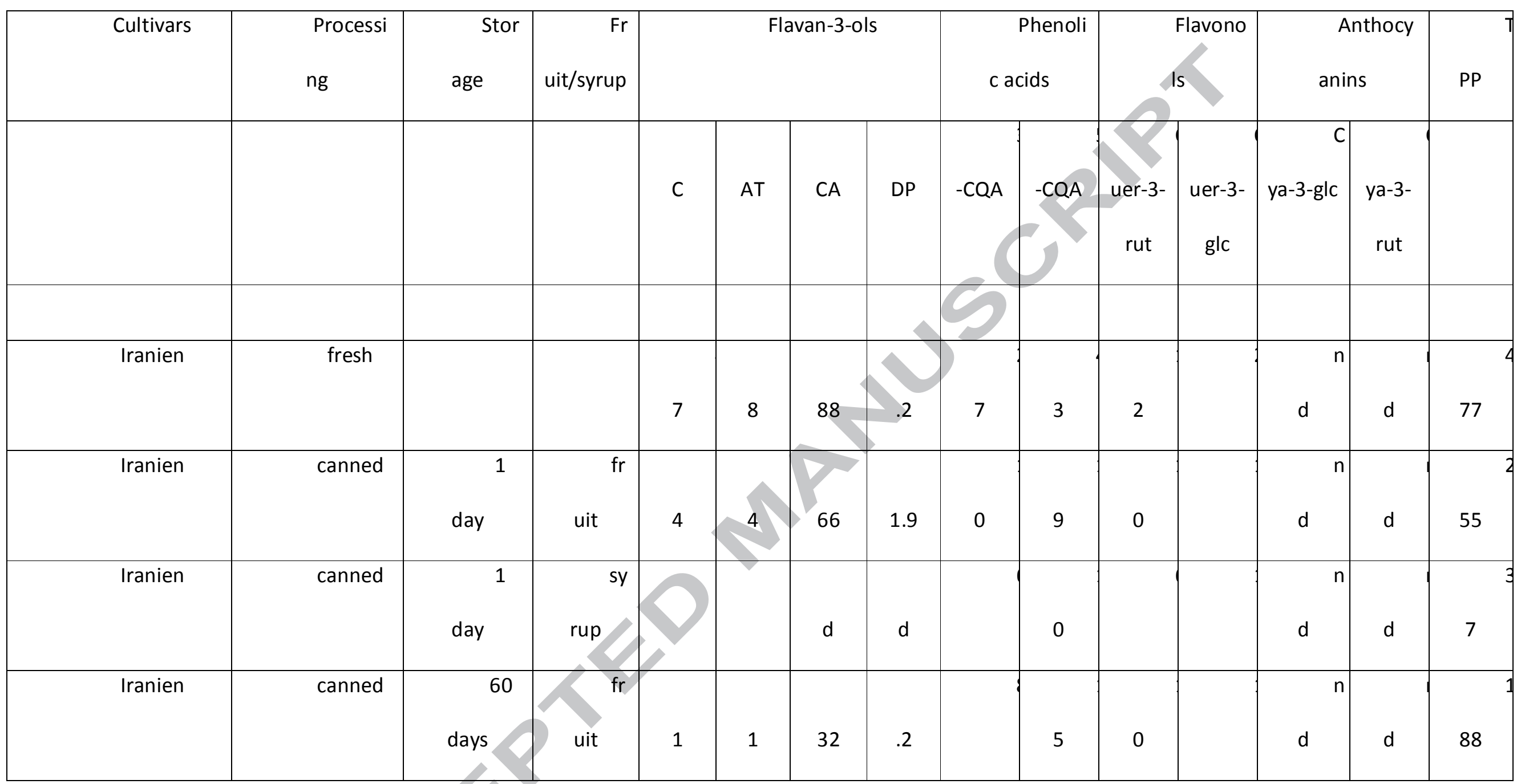


ACCEPTED MANUSCRIPT

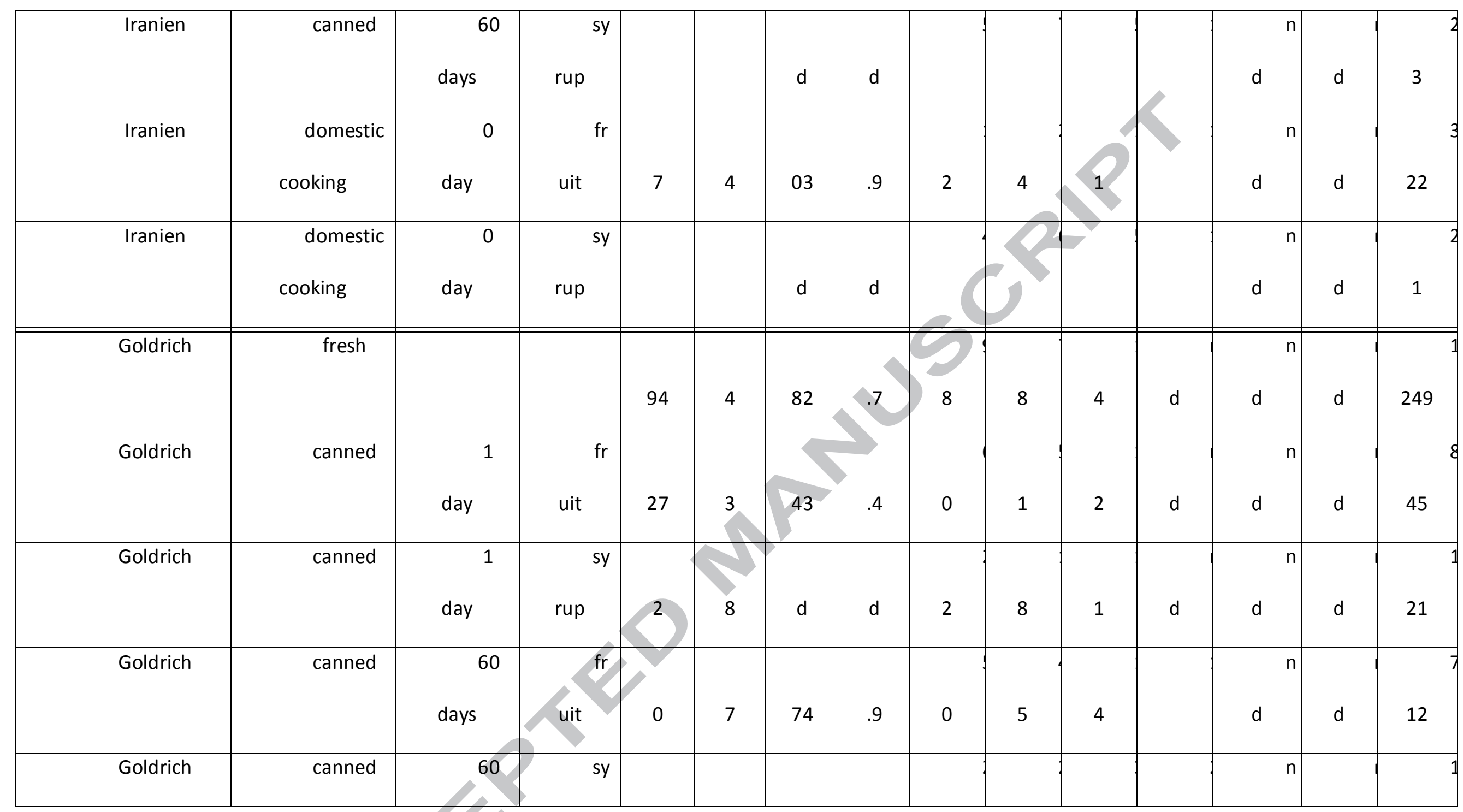


ACCEPTED MANUSCRIPT

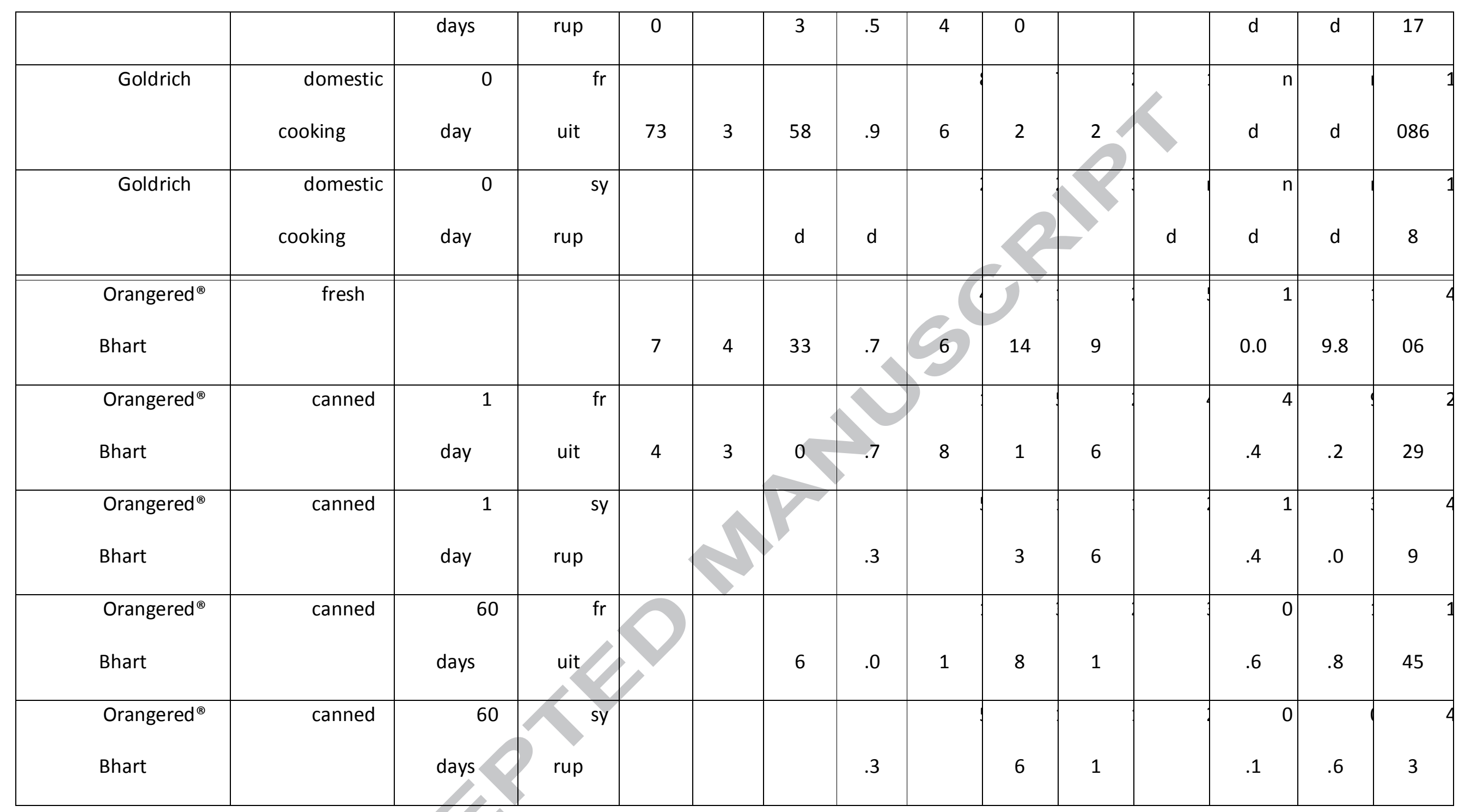




\section{ACCEPTED MANUSCRIPT}

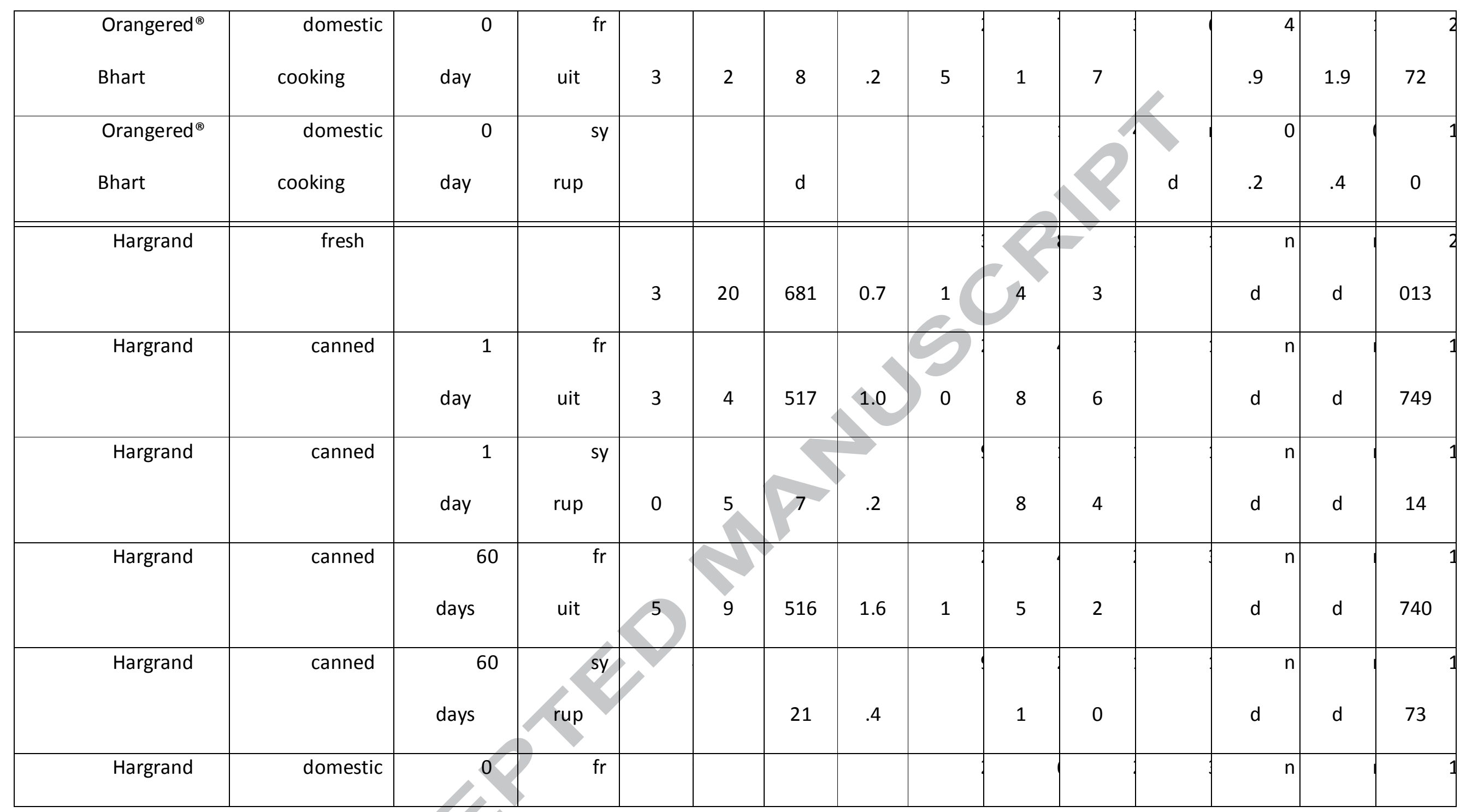




\section{ACCEPTED MANUSCRIPT}

\begin{tabular}{|c|c|c|c|c|c|c|c|c|c|c|c|c|c|c|}
\hline & cooking & day & uit & 2 & 13 & 641 & .3 & 7 & 2 & 8 & & $d$ & $d$ & 966 \\
\hline \multirow[t]{2}{*}{ Hargrand } & domestic & 0 & sy & & & & & & & & & $n$ & & 1 \\
\hline & cooking & day & rup & & & $d$ & $d$ & & & & & $d$ & $d$ & 0 \\
\hline \multirow[t]{2}{*}{ Statistics } & & Pool & & & & & & & & & & 0 & & 5 \\
\hline & & ed SD & & .2 & .2 & 6.2 & .4 & .2 & & 8 & .4 & .5 & .0 & 6.1 \\
\hline \multicolumn{15}{|c|}{ F value and } \\
\hline significance & & & & & & & & & & & & & & \\
\hline \multirow[t]{3}{*}{ Cultivar } & & & & & & & 7 & & & & & 2 & & 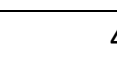 \\
\hline & & & & 07.32 & 6.61 & 6.21 & 1.99 & 6.6 & 6.81 & 5.43 & 7.31 & 2.35 & 1.91 & 6.83 \\
\hline & & & & & * & $* *$ & $*$ & $* *$ & $* *$ & $*$ & $* *$ & $*$ & $* *$ & $* *$ \\
\hline \multirow[t]{2}{*}{ Process } & & & & & & & & & & & & 1 & & \\
\hline & & & & 3.28 & 6.92 & .87 & .21 & 3.48 & 8.20 & 6.10 & 0.57 & 6.87 & 4.11 & 0.81 \\
\hline & & & & & & & & & & & & $*$ & & \\
\hline
\end{tabular}




\section{ACCEPTED MANUSCRIPT}

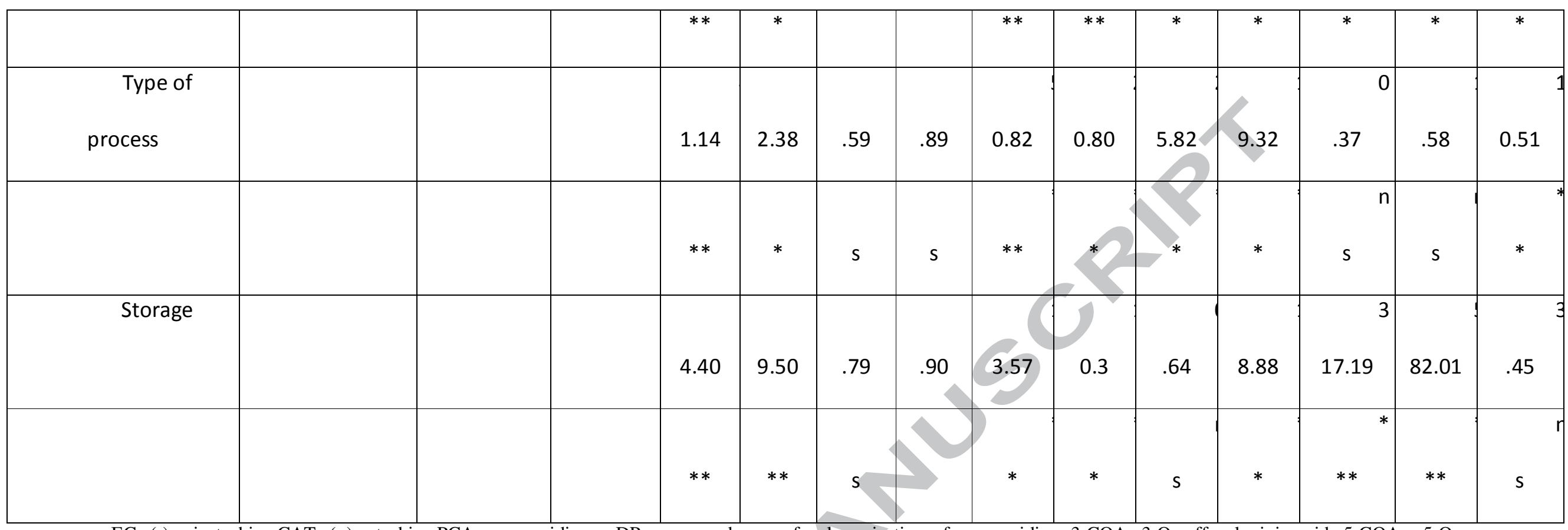

EC: (-)-epicatechin, CAT: (+)-catechin, PCA: procyanidins, mDP: average degree of polymerization of procyanidins, 3-CQA: 3-O-caffeoylquinic acid, 5-CQA : 5-O-

caffeoylquinic acid, Quer-3-rut: quercetin-3-O-rutinoside, Quer-3-glc: quercetin-3-O-glucoside, Cya-3-glc: cyanidine-3-O-glucoside, Cya-3-rut: cyanidine-3-O-rutinoside,

TPP: total polyphenols, $\mathrm{Nd}:$ not detected, pooled $\mathrm{SD}:$ pooled standard deviation $\mathrm{ddl}=56$, ns : non significant, * $(\mathrm{P} \leq 0.05), * *(\mathrm{P} \leq 0.01), * * *(\mathrm{P} \leq 0.001)$. Values are means of

3 replicates. 


\section{ACCEPTED MANUSCRIPT}

Table 3: Carotenoids concentrations $\left(\mathrm{mg} \mathrm{kg}^{-1} \mathrm{FW}\right)$ in apricots as function of cultivars, processing and storage.

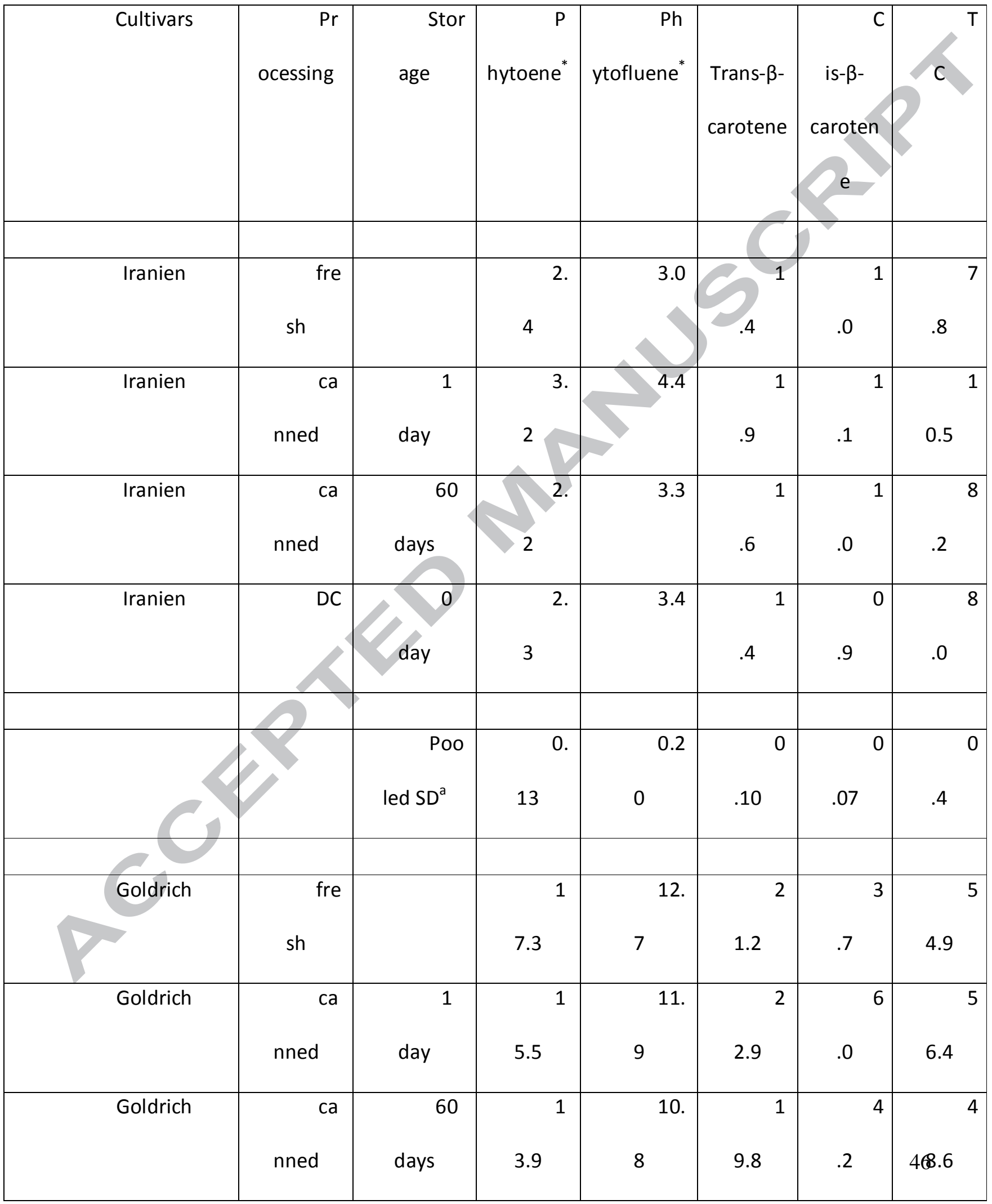




\section{ACCEPTED MANUSCRIPT}

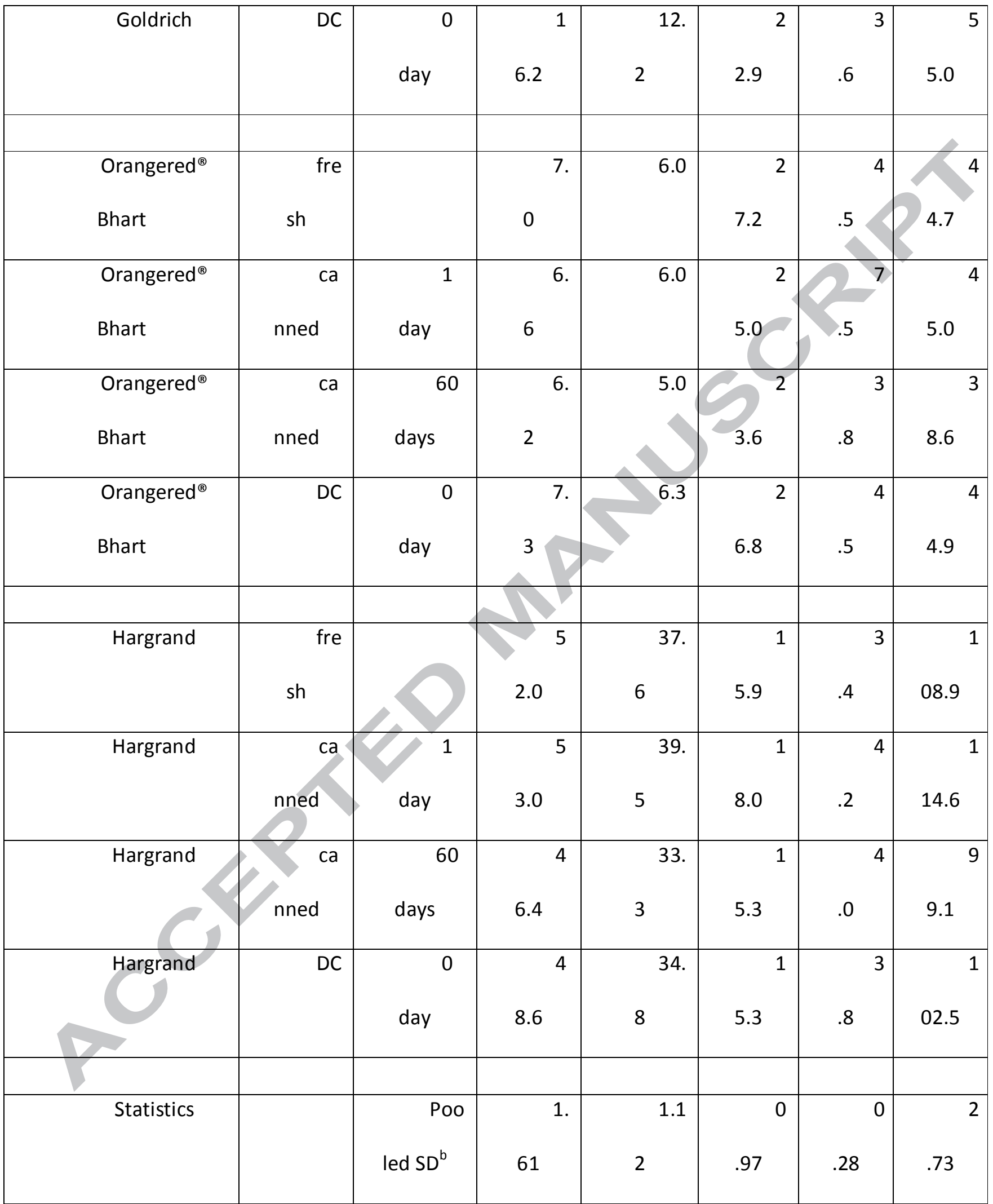




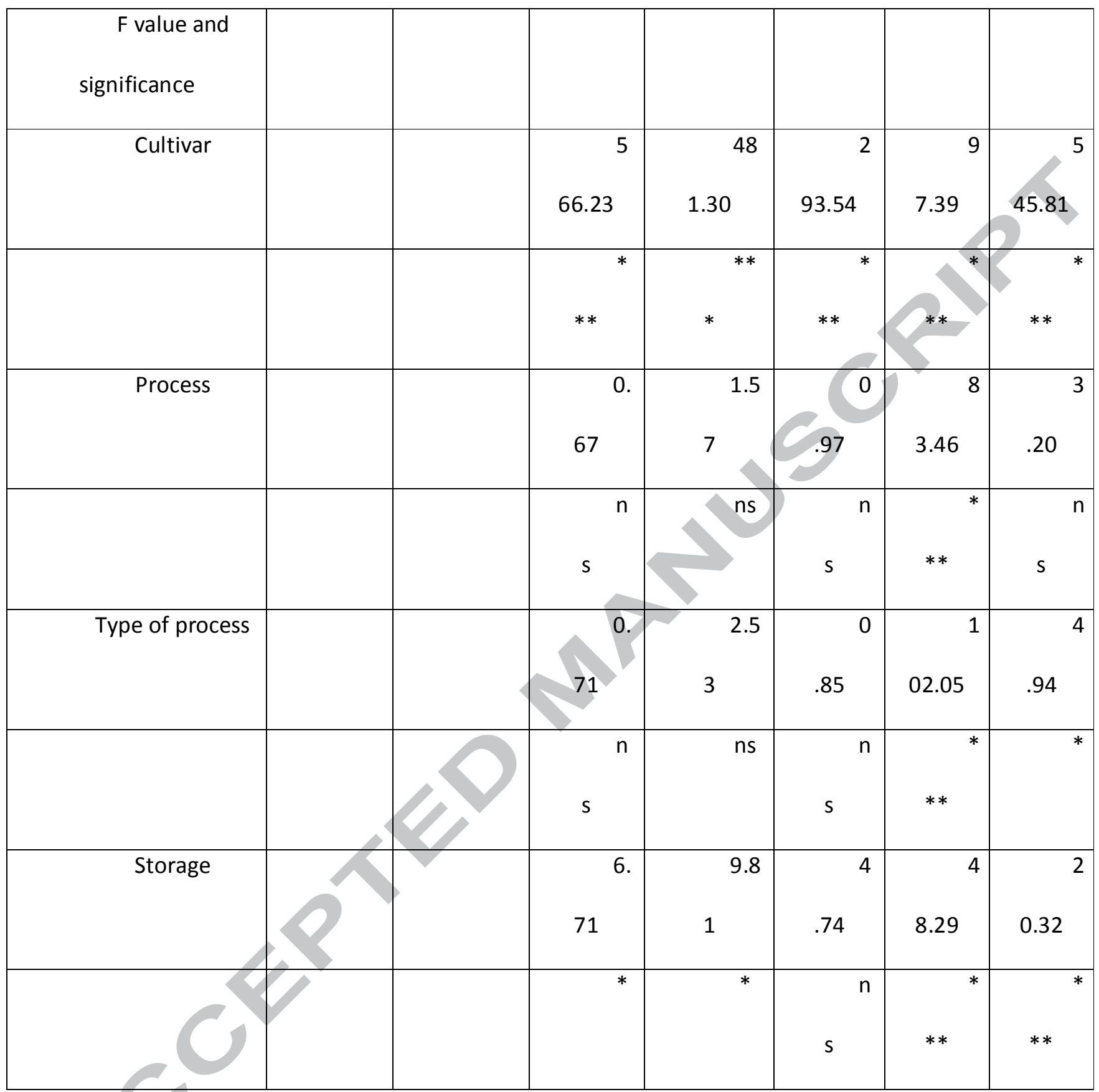

DC: domestic cooking, TC: total carotenoids. *quantified as equivalent of $\beta$-Carotene, pooled SD: pooled standard deviation, a: $\mathrm{ddl}=8$, b: $\mathrm{ddl}=24, \mathrm{~ns}$ (non significant), * $(\mathrm{P} \leq 0.05),{ }^{* *}(\mathrm{P} \leq 0.01),{ }^{* * *}(\mathrm{P} \leq 0.001)$. Values are means of 3 replicates. 


\section{Highlights}

Apricot carotenoids are more stable than phenolics upon thermal treatments

Polyphenol losses are mainly due to thermal degradation and leaching Apricot phenolic are more stable than carotenoids upon storage 